\title{
Feeding rumen-protected lysine to dairy cows prepartum improves performance and health of their calves
}

\author{
B. L. Thomas, ${ }^{1}$ A. R. Guadagnin, ${ }^{1} \odot$ L. K. Fehlberg, ${ }^{1} \odot$ Y. Sugimoto, ${ }^{2}$ I. Shinzato, ${ }^{2}$ J. K. Drackley, ${ }^{1}{ }^{\oplus}$ \\ and F. C. Cardoso ${ }^{1 *}$ (D) \\ ${ }^{1}$ Department of Animal Sciences, University of Illinois, Urbana 61801 \\ ${ }^{2}$ Ajinomoto Co. Inc., Tokyo, Japan 104-8315
}

\begin{abstract}
Providing adequate concentrations of AA in the prepartum diet is pivotal for the cow's health and performance. However, less is known about the potential in utero effects of particular AA on early-life performance of calves. This experiment was conducted to determine the effects on dairy calves when their dams were fed rumen-protected lysine (RPL; AjiPro-L Generation 3, Ajinomoto Heartland Inc.; $0.54 \%$ dry matter of total mixed ration as top dress) from $26 \pm 4.6 \mathrm{~d}$ (mean \pm standard deviation) before calving until calving. Seventy-eight male (M) and female (F) Holstein calves were assigned to 2 treatments based on their dams' prepartum treatment, RPL supplementation (PRE-L) or without RPL (CON). At the time of birth (0.5-2 h after calving), before colostrum was fed, blood samples were collected. An initial body weight was obtained at 1 to $3 \mathrm{~h}$ after birth. Calves were fed $470 \mathrm{~g}$ of colostrum replacer (Land O'Lakes Bovine IgG Colostrum Replacer, Land O'Lakes, Inc.) diluted in 3.8 L of water. Calves were provided water ad libitum and fed milk replacer (Advance Excelerate, Milk Specialties Global Animal Nutrition; $28.5 \%$ crude protein, $15 \%$ fat) at $0600 \mathrm{~h}$ and $1700 \mathrm{~h}$ until $42 \mathrm{~d}$ of age. Calves were measured weekly, at weaning (d 42), and at the end of the experimental period (d 56). Plasma concentrations of AA were measured on $\mathrm{d} 0,7$, and $14 \mathrm{~d}$ using ultra-performance liquid chromatography-mass spectrometry (Waters) with a derivatization method (AccQ-Tag Derivatization). Final body weight was greater for $\mathrm{M}(87 \pm 11 \mathrm{~kg})$ than F $(79 \pm 7 \mathrm{~kg})$. Calves in PRE-L tended to have greater dry matter $(814 \pm 3 \mathrm{~g} / \mathrm{d})$ and crude protein $(234 \pm 6$ $\mathrm{g} / \mathrm{d})$ intakes than those in CON $(793 \pm 9 \mathrm{~g} / \mathrm{d}$ and 228 $\pm 11 \mathrm{~g} / \mathrm{d}$, respectively). Calves in PRE-L had greater average daily gain $(0.96 \pm 0.04 \mathrm{~kg} / \mathrm{d})$ than calves in CON $(0.85 \pm 0.03 \mathrm{~kg} / \mathrm{d})$ during wk 6 to 8 . Calves in
\end{abstract}

Received March 30, 2021.

Accepted October 17, 2021.

*Corresponding author: cardoso2@illinois.edu
PRE-L tended to be medicated fewer days than CON $(4.7 \pm 1.2 \mathrm{~d}$ vs. $6.2 \pm 3.4 \mathrm{~d}$, respectively). Calves in PRE-L-M and CON-F $(2,916 \pm 112 \mu M$ and $2,848 \pm$ $112 \mu M$, respectively) had greater total AA concentration in plasma than calves in PRE-L-F and CON-M $(2,684 \pm 112 \mu M$ and $2,582 \pm 112 \mu M$, respectively). Calves in PRE-L-F and CON-M (4.09 $\pm 0.11 \%$ and $4.16 \pm 0.11 \%$, respectively) had greater concentration of Lys as a percentage of total AA compared with calves in CON-F and PRE-L-M $(3.91 \pm 0.11 \%$ and $3.90 \pm 0.11 \%$, respectively). Calves in PRE-L tended to have greater percentage of phagocytic neutrophils $(39.6 \pm 1.59 \%)$ than calves in CON $(35.9 \pm 1.59 \%)$. In conclusion, increasing the metabolizable lysine provided to prepartum dairy cows had modest effect over offspring performance, with the major result being a greater average daily gain for calves in PRE-L during the preweaning phase (wk 6-8).

Key words: average daily gain, amino acid, in utero, phagocytosis

\section{INTRODUCTION}

The process of giving birth for mammals can be a stressful time for both the dams (Drackley, 1999) and offspring (Laporta et al., 2017). During late gestation, cows maintain growth and development of the fetus, go through a dry-off process, and have a dietary change (Carder and Weiss, 2017). Methionine and Lys are usually the most limiting AA in dairy cattle diets (NRC, 2001), which is true for calves as well (van den Borne et al., 2012). Additionally, Bell et al. (2000) postulated that the NRC (2001) overestimates the efficiency of AA uptake by the uterus during the prepartum period, thereby underestimating the MP requirement for dairy cows in late gestation. It is important to maintain the required AA, especially Lys, to support fetal growth and subsequent milk production and components (Rogers et al., 1987; Lee et al., 2019).

Calf raising is of utmost importance as calves are the future milk producers, but it is also challenging to pro- 
duce high-quality replacement heifers (Heinrichs, 1993). One of the most important aspects of calf management is to keep calves healthy, both as matter of guaranteeing animal welfare and because high rates of morbidity and mortality result in big economic losses (Tautenhahn et al., 2020). Diseases can affect the growth of calves (McLean and Bailey, 1972). Calves with compromised immune systems from suboptimal nutrition (McLean and Bailey, 1972) are more susceptible to diarrhea and pneumonia, which are health-related problems commonly found in calf management (USDA, 2010). Scours in calves are commonly caused by the ingestion of a pathogen (i.e., Escherichia coli; Foster and Smith, 2009). Pneumonia is responsible for $46.5 \%$ of preweaning and weaned calf deaths, with an estimated cost of almost $\$ 15$ per calf per year (Donovan et al., 1998; USDA, 2010). Dairy calves that are diagnosed with pneumonia have poor growth, reproductive performance, and milk production in the future (Waltner-Toews et al., 1986; Weigler et al. 1990; Warnick et al., 1997). At birth, calves are considered unable to mount an effective and successful immune response, hence the importance of colostrum management (Barrington and Parish, 2001).

In addition to providing the appropriate amount of quality colostrum, improvement in the immune function of calves can help reduce these health problems (Dunn et al., 2017). All essential immune components are present in neonates because the development of immune defense mechanisms starts in utero (Barrington and Parish, 2001). Moreover, the placenta is a central programming agent of adult health and disease (Gabory et al., 2013). Environmental stimuli, such as maternal nutrition, can alter fetal nutrient supply (Tarrade et al., 2015). Therefore, the maternal diet is an important factor to guarantee offspring health and performance (Barua e Junaid, 2015). Alharthi et al. (2018) evaluated the effects of rumen-protected methionine (RPM) supplementation to cows' diets prepartum and its effects on their offspring. The authors reported a positive effect on calf growth where the calves from cows fed RPM had greater BW (mean \pm SD; 44.1 vs. $42.1 \pm$ $0.70 \mathrm{~kg}$ ), hip height $(81.3$ vs. $79.6 \pm 0.53 \mathrm{~cm})$, and withers height $(77.8$ vs. $75.9 \pm 0.47 \mathrm{~cm})$ than calves from cows that did not receive RPM. These effects are attributed to alterations in the uteroplacental transport of indispensable and dispensable (i.e., nonessential) AA and glucose, as well as mammalian target of rapamycin (mTOR) signaling (Batistel et al., 2017). It is possible that Lys could also affect uteroplacental transport of nutrients through similar mechanisms. Lin et al. (2018) reported an increase in the mTOR downstream targets 4EBP1 and S6K1 in response to Lys.

Although the majority of Lys metabolism happens in tissues such as mammary gland and liver (Lapierre et al., 2009), recent literature indicates that Lys might be oxidized and utilized in different tissues, such as brain and kidney (Pink et al., 2011; Gatrell et al., 2013). Considerable research on fetal programming has been conducted with nonruminant species, mostly focusing on animals that can model studies for humans, and the importance of nutrient manipulations during late pregnancy and their influence in fetal and postnatal development of the offspring is evident (Godfrey and Barker, 2001; Gao et al., 2012). Therefore, we hypothesized that maternal supplementation of rumen-protected lysine (RPL) during late gestation would benefit the growth and development of the calves due to a greater in utero transfer of Lys and other indispensable AA (IAA). The objective of this study was to determine the effect of RPL fed to dams and the effect of the sex of their calves on their calves' growth performance, health, and blood metabolite concentrations during the first $56 \mathrm{~d}$ of life.

\section{MATERIALS AND METHODS}

\section{Animal Care and Housing}

All experimental procedures were approved by the University of Illinois (Urbana-Champaign) Institutional Animal Care and Use Committee (protocol \#18157), and cow management is reported elsewhere (Fehlberg et al., 2020). Briefly, 83 multiparous Holstein cows were blocked by parity (mean $\pm \mathrm{SD} ; 3.3$ \pm 1.1 ), previous 305 -d mature-equivalent milk production $(11,363 \pm 1,860 \mathrm{~kg})$, expected calving date, and BCS during far-off period $(3.76 \pm 0.84)$. Cows were then assigned to 1 of 2 dietary treatments in a randomized, complete block design. Dietary treatments consisted of a diet with RPL [AjiPro-L Generation 3, Ajinomoto Heartland Inc.; 0.54\% DM of TMR as top dress; PRE-L ( $\mathrm{n}=41)$ ] or without RPL [CON (n = 43)] top dressed in a carrier of $300 \mathrm{~g}$ of dried sugarcane molasses. According to the manufacturer, there is $80 \%$ rumen bypass and $80 \%$ intestinal digestibility to result in $64 \%$ bioavailability of this encapsulated RPL product (Miura et al., 2017). This would provide 1.4 $\mathrm{g}$ of intestinally available Lys prepartum per kilogram of DMI. Diets (TMR) were formulated using AMTS. Cattle.Pro version 4.7 (2017, AMTS LLC) to meet or exceed recommendations. The prepartum diet was formulated for cows weighing approximately $694 \mathrm{~kg}$ and having a predicted DMI of $13 \mathrm{~kg} / \mathrm{d}$. After calving, cows were moved into a tiestall barn, and all calves were placed in individual hutches (Calf-Tel, Hample Corp.). Hutches were placed on a layer of limestone, which was covered with straw. Straw was checked daily and more was added as needed. Calves were in the hutches for 56 
d. The number of cows per treatment was calculated to detect a minimum of $7 \%$ difference in postpartum DMI between groups, assuming a power of 0.9 and a 2 -tailed $\alpha$ of 0.05. All calves from cows who were not excluded from the study were enrolled in the study. The exclusion criteria included calving with twins or not having consumed the treatment for at least $16 \mathrm{~d}$ during the prepartum period. Interventions were administered and outcomes were assessed by personnel who were blinded to group assignments.

\section{Birth Processing of Calves}

Female $(\mathbf{F}, \mathrm{n}=41)$ and male $(\mathbf{M}, \mathrm{n}=42)$ calves from both treatments were evaluated. At the time of birth (0.5-2 $\mathrm{h}$ after calving), calves were removed from the dams to perform newborn processing procedures. No colostrum from the dams was fed to calves; instead, calves were fed $470 \mathrm{~g}$ of colostrum replacer (Land O'Lakes Bovine IgG Colostrum Replacer, Land O'Lakes, Inc.) diluted with $3.8 \mathrm{~L}$ of water. Calves received 1 oral dose of bovine coronavirus-Escherichia coli antibody (First Defense, Immucell Corp.) and were vaccinated intranasally with $2 \mathrm{~mL}$ of a modified live bovine Rhinotracheitis and parainfluenza-3 virus vaccine (TSV-2; Zoetis) and orally with $3 \mathrm{~mL}$ of a modified live bovine rotavirus and coronavirus vaccine (Calf-Guard; Zoetis). Each calf was identified with an ear tag, and its navel cord was dipped with $10 \%$ tincture of iodine solution (VEDCO Inc.). On the same day they were born, calves were dehorned using paste (Dr. Naylor Dehorning Paste, H. W. Naylor Company Inc.). Initial measurements of BW were obtained after calving ( $0.5-3 \mathrm{~h}$ of after birth) and before feeding colostrum replacer. On $\mathrm{d} 7$ of age, calves received $2 \mathrm{~mL}$ of Clostridium perfringens Type C\&D bacterin toxoid (Ultrabac CD, Zoetis). All male calves were castrated at $16 \pm 4 \mathrm{~d}$ of age. Of calves included in the final data, $\beta$-casein genetics were determined and presented in Supplemental Table S1 (https://uofi.box .com/s/qq7ubtzvbr9wxpobczdc7fno2t108ajt).

\section{Feeding Management}

Calves were fed milk replacer (MR; Advance Excelerate, Milk Specialties Global Animal Nutrition; 28.5\% $\mathrm{CP}, 15 \%$ fat) twice daily at 0600 and $1700 \mathrm{~h}$ for the first $42 \mathrm{~d}$ of life. The MR ratio was $0.59 \mathrm{~kg}$ of MR powder to $3.95 \mathrm{~L}$ of warm water. Calves received increments of total MR as $4.54 \mathrm{~kg}$ of liquid per day from 1 to 10 d of age, $5.9 \mathrm{~kg} / \mathrm{d}$ from 11 to $20 \mathrm{~d}$ of age, and $7.26 \mathrm{~kg}$ from 21 to $35 \mathrm{~d}$ of age. On d 36 to 42 , weaning began by giving $3.63 \mathrm{~kg} / \mathrm{d}$ of MR only at the $0700 \mathrm{~h}$ feeding. A nonantibiotic anticoccidial $(1.25 \mathrm{~g} / \mathrm{d}$; Deccox $6 \%$, Zo- etis) was added to the MR each morning. Grain starter (19.9\% CP, 13.5\% NDF, Ampli-Calf Starter, Purina) was provided from d 1 of age until d 56 for ad libitum intake at $1600 \mathrm{~h}$. Milk replacer and starter amounts were recorded when fed. All refusals were measured and recorded. Water was provided for ad libitum intake for the duration of the experiment.

\section{Feed Analysis}

Milk replacer, colostrum replacer, and starter grain were sampled weekly, and samples were stored at $-20^{\circ} \mathrm{C}$. Samples were composited by month and were analyzed by Dairy One (Dairy One Cooperative Inc.). The MR and colostrum replacer were analyzed through wet chemistry for contents of DM (method 935.29), CP (method 976.06), ether extract (method 920.39), ash (method 2000.18), Ca, P, Mg, K, Na, Fe, Zn, Cu, Mn, Mo, and S (Dairy One, 2009) according to AOAC International $(2002,2005,2019)$ and Dairy One (2009) methods (Table 1). The starter diet was analyzed for DM (method 925.40), CP (method 955.04), acid detergent insoluble $\mathrm{CP}$ and neutral detergent insoluble CP according to Licitra et al. (1996), ADF (method 973.18), aNDFom (amylase NDF corrected for OM; Mertens, 2002), lignin (Mertens, 2002), starch (method 996.11), ethanol-soluble carbohydrates (simple sugars, method 985.29), ether extract (method 920.39), ash (method 2000.18), Ca, P, Mg, K, Na, Fe, Zn, Cu, Mn, $\mathrm{Mo}, \mathrm{S}$, and $\mathrm{Cl}$ (Dairy One, 2009) [(AOAC International, 2002, 2005, Mertens, 2002; Dairy One, 2009) Table 1].

\section{Body Growth and Measurements}

Initial BW was measured at birth. Body weight, body length, heart girth (HG), withers height, hip width, and hip heights were measured weekly for the duration of the trial. Two additional measurements were made at weaning (d 42) and completion of trial (d 56). Measurements were made on the same day of every week at $1700 \mathrm{~h}$.

\section{Health}

Health checks were completed weekly. Fecal scores were assessed on a scale of 1 to 4 as follows: $1=$ normal and well formed; $2=$ soft, semi-formed, pasty; $3=$ loose, but stayed on top of bedding; and $4=$ watery, sifts through bedding. Respiratory scores were assigned on a scale of 1 to 4 as follows: $1=$ normal; $2=$ induced a single cough or open mouth breathing; $3=$ induced repeated or spontaneous coughs with open mouth breathing and mucus; $4=$ dry or wet cough repeated 
Table 1. Mean chemical composition and associated standard deviations for milk replacer powder, ${ }^{1}$ colostrum replacer powder ${ }^{2}$ and calf starter ${ }^{1}$ fed to all calves throughout the experimental period

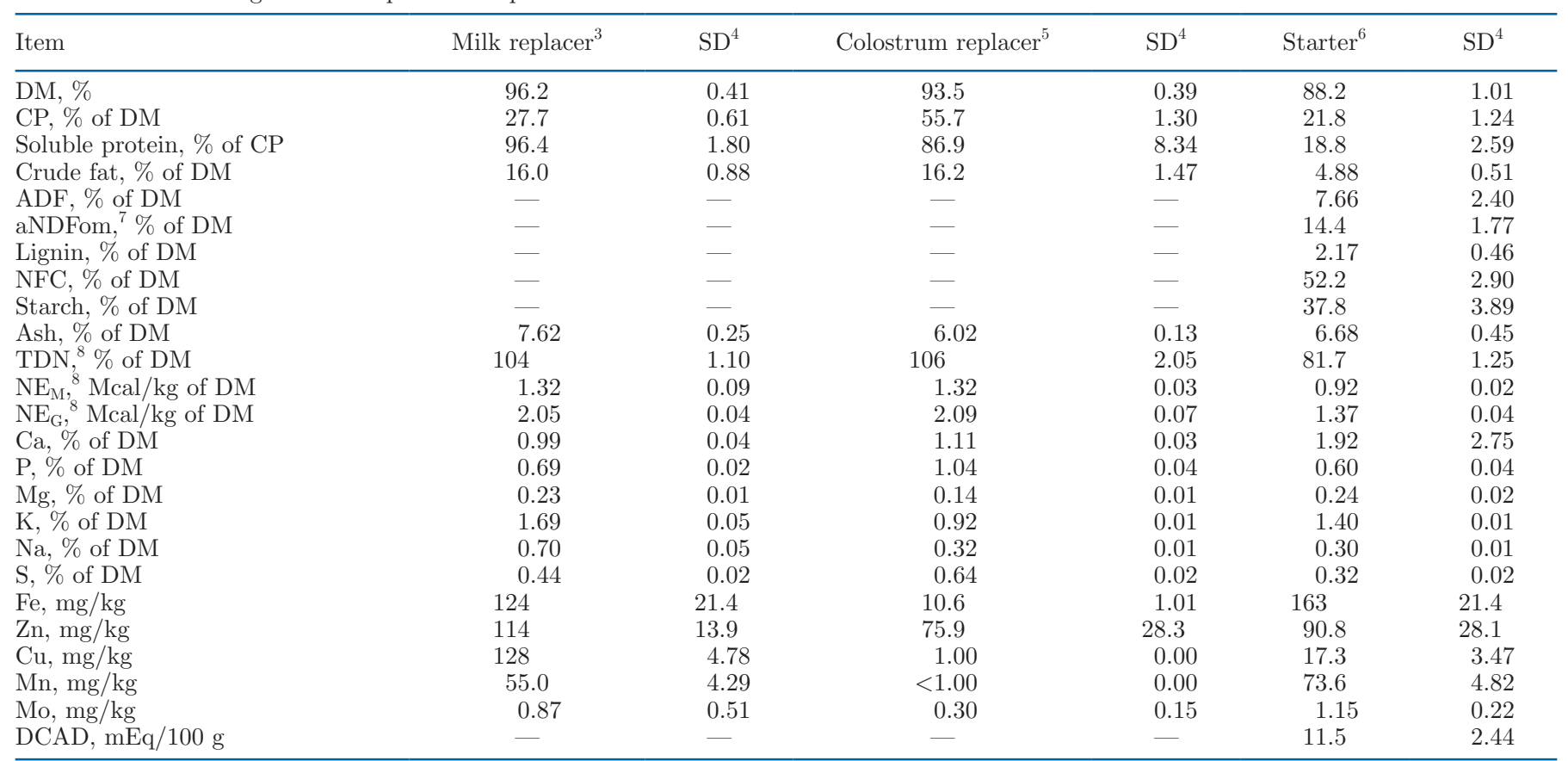

${ }^{1}$ Mean diet sampled once weekly, composited monthly throughout experimental period $(\mathrm{n}=11)$.

${ }^{2}$ Mean diet sampled once weekly, composited monthly throughout experimental period $(\mathrm{n}=9)$.

${ }^{3}$ Milk Replacer was given 1 to $42 \mathrm{~d}$ of life (Advanced Excelerate, Milk Specialties).

${ }^{4}$ Maximum SD with all samples.

${ }^{5}$ Colostrum replacer was given at birth (Land O'Lakes Bovine IgG Colostrum Replacer, Land O'Lakes, Inc.).

${ }^{6}$ Calf starter was given from d 0 to 56 (Ampli-Calf Starter, Purina).

${ }^{7}$ aNDFom $=$ amylase neutral detergent fiber organic matter.

${ }^{8} \mathrm{NRC}(2001)$.

spontaneous for several days. A nasal, eyes, and ear score were assigned on a scale of 1 to 4 , where $1=$ normal to $4=$ heavy discharge. Rectal temperatures were measured weekly. All scales were assigned based on a health chart system (School of Veterinary Medicine, University of Wisconsin-Madison). Calves with a fecal score greater than 2 were given orally $100 \mathrm{~g}$ of electrolytes in $1.89 \mathrm{~L}$ of water (Diaque, Boehringer Ingelheim) for $5 \mathrm{~d}$ at the 0700 feeding. Additionally, calves received $5 \mathrm{~mL}$ of vitamin B complex (Vitamin B complex HP, Vet One) intramuscularly. If the fecal scores were severe (score of 4 with a temperature $>39.7^{\circ} \mathrm{C}$ and other health problems; e.g., refusal of milk), $6 \mathrm{~mL}$ of penicillin (Combi-Pen-48, Bimeda Inc.) was also given for $5 \mathrm{~d}$ intramuscularly. Calves with a respiratory score greater than 2 were treated with $2.5 \mathrm{mg} / \mathrm{kg}$ of tulathromycin (Draxxin, Zoetis) subcutaneously. Any calf that had a temperature greater than $39.7^{\circ} \mathrm{C}$ received 1.1 to $2.2 \mathrm{mg} /$ $\mathrm{kg}$ of intravenous of flunixin meglumine (Banamine, Zoetis). Any calves that needed medical attention beyond farm protocol were taken to the University of Illinois
Veterinary Medicine Teaching Hospital, where feedings and health scores were not recorded. All other sickness was treated according to farm protocol and veterinary attention.

\section{Blood Collection and Analysis}

The blood chemistry profile was measured on d 0,2 , 7,14 , and 28. The period for plasma AA and phagocytosis and oxidative burst measurement consisted of $\mathrm{d} 0$, 7, and 14. Immunophenotyping of T cells [CD4, CD8, and $\gamma \delta]$ was conducted on $\mathrm{d} 0$ and 7 . Blood samples were taken at $1600 \mathrm{~h}$, before measurements of refusals, from the jugular vein into five 8-mL tubes (2 evacuated heparin tubes, $1 \mathrm{~K}_{2}$ EDTA tube, and 2 serum separation tubes; Becton Dickinson) that were centrifuged at 1,500 $\times g$ for 15 min at $4^{\circ} \mathrm{C}$ to obtain plasma and serum.

Serum samples were sent to the University of Illinois Veterinary Diagnostic Laboratory (https:// vetmed.illinois.edu/vet-resources/veterinary-diagnostic -laboratory/). Serum was analyzed for creatinine, BUN, 
$\mathrm{TP}$, albumin, globulin, $\mathrm{Ca}, \mathrm{P}, \mathrm{Na}, \mathrm{K}, \mathrm{Cl}, \mathrm{Mg}$, glucose, total alkaline phosphatase (ALP), aspartate aminotransferase, gamma-glutamyl transpeptidase (GGT), total bilirubin (TB), creatine phosphokinase, cholesterol, glutamate dehydrogenase (GLDH), bicarbonate, triglycerides, and anion gap via the large animal chemistry profile (University of Illinois Diagnostics Lab, Urbana, IL). Plasma concentrations of AA were measured using an ultra-performance liquid chromatography-MS (Waters; Armenta et al., 2010) with the derivatization method (AccQ-Tag Derivatization) provided by the manufacturer.

The phagocytosis function and oxidative burst activity of peripheral monocytes and neutrophils was determined by challenging the blood with enteropathogenic bacteria (E. coli 0118:H8) as described by Zhou et al. (2016). Briefly, $200 \mu \mathrm{L}$ of whole blood was incubated with $40 \mu \mathrm{L}$ of $100 \mu M$ dihydroergotamine (Sigma-Aldrich) and $40 \mu \mathrm{L}$ of propidium iodide-labeled bacteria $\left(10^{9} \mathrm{cfu} / \mathrm{mL}\right)$ at $38.5^{\circ} \mathrm{C}$ for $10 \mathrm{~min}$. The red blood cells were lysed with ice-cold MilliQ water, and cells were resuspended in PBS. Monocytes were tagged with allophycocyanin anti-CD14 antibody (cat. no. 301808; Biolegend), and neutrophils were stained with CH138A primary anti-bovine granulocyte monoclonal antibody (cat. no. BOV2067, Washington State University) and phycoerythrin-labeled secondary antibody (cat. no. 1020-09S). The cells were then resuspended in PBS solution for flow cytometry analyses (LSR II; Becton Dickinson). Data were reported as percentages of CD14/CH138A positive monocytes and neutrophils with phagocytosis and oxidative burst potential.

The $\gamma \delta$ T cells for naïve CD4 and CD8 T-cell activity were determined as described by Park et al. (2015). Briefly, using a SepMate tube (StemCell Technologies cat no. 15415), $200 \mu \mathrm{L}$ of whole blood with $40 \mu \mathrm{L}$ of Lymphoprep (cat no. 07851, StemCell Technologies) were centrifuged together to extract buffy coat from the plasma. The white blood cells were washed with wash buffer (PBS $+2 \%$ fetal bovine serum), and then suspended in blocking solution (staining buffer $+2 \%$ fetal porcine serum). Lymphocytes for CD4 and CD8 T cells were tagged with IL11A, 7C2B, and ILA116A antibodies, and $\gamma \delta \mathrm{T}$ cells were tagged with GB21A antibodies (cat. no. BOV2010, BOV2019, BOV2042, and BOV2058, respectively; Monoclonal Antibody Center, Washington State University) and PE-labeled secondary antibody (Cat. No. 1020-09S, Southern Biotech). The cells were then resuspended in staining buffer solution for flow cytometry analyses (LSR II; Becton Dickinson). Data were reported as percentages of CD4/ IL11A, CD8/7C2B, and GB21A/ $\gamma \delta$ with positive lymphocyte activity.

\section{Statistical Analyses}

Statistical analyses were conducted using MIXED, FREQ, and GLIMMIX procedures of SAS (v. 9.4, SAS Institute Inc.). The following model was used:

$$
\begin{aligned}
Y_{j k l}=\mu+ & B_{j}+A_{k}+S_{l}+T_{m}+(A S)_{k l}+(A T)_{j m} \\
& +(S T)_{l m}+(A S T)_{k l m}+\varepsilon_{j k l},
\end{aligned}
$$

where $Y_{j k l}=$ observations for dependent variables; $\mu=$ overall mean $B_{j}=$ fixed effect of block; $A_{k}=$ fixed effect of treatment; $S_{l}=$ fixed effect of sex; $T_{m}=$ repeated effect of time; $(A S)_{k l}=$ interaction of treatment and sex; $(A T)_{j m}=$ interaction of treatment and time; $(S T)$ $l_{l m}=$ interaction of sex and time; $(A S T)_{k l m}=$ interaction of treatment and sex and time; and $\varepsilon_{j k l}=$ random residual error. The estimation method was restrictive maximum likelihood, and the degrees of freedom method was Kenward-Roger (Littell, 2002). Variables were subjected to 5 covariance structures as follows: compound symmetry, unstructured, autoregressive order 1, autoregressive heterogeneous order 1, and Toeplitz. Compound symmetry was the covariance structure that yielded the lowest corrected Akaike information criterion and was used in the model (Littell, 2002). Calf was the experimental unit and was considered a random effect. A log-transformation for the variables ADG, plasma AA variables, glucose, glutamate dehydrogenase, triglyceride, creatinine, creatine phosphokinase, anion gap, bicarbonate, BUN, total protein, albumin, $\mathrm{P}$, $\mathrm{Na}, \mathrm{K}, \mathrm{Cl}$, aspartate aminotransferase, GGT, bilirubin, ALP, and gamma delta T cells was performed because their model residuals were not normally distributed and with homogeneous variance. Frequency analysis was performed using the FREQ. Models for medication of calves (with electrolytes, antibiotics, or both) were evaluated by logistic regression using a binomial distribution in the GLIMMIX procedure in SAS. Odds ratio was used to compare the likelihood of 2 treatments to incur any event. Significance was declared at $P \leq 0.05$ and trends at $0.05<P \leq 0.10$.

\section{RESULTS}

Data from 78 calves [CON-F $(\mathrm{n}=20)$; CON-M (n $=17)$; PRE-L-F $(\mathrm{n}=18)$; PRE-L-M $(\mathrm{n}=23)]$ were obtained. Overall, 5 calves from the CON treatment died. Three females and 1 male died of clostridial bloat (on d 4, 8, 10, and 18). One male was euthanized on d 2 due to a broken leg from complications at birth. One male from PRE-L was euthanized for feeding problems on d 2 of life. During the study, 5 calves required off- 
Table 2. Least squares means and associated standard errors for intakes of DM, CP, and ME of calves throughout the experimental period

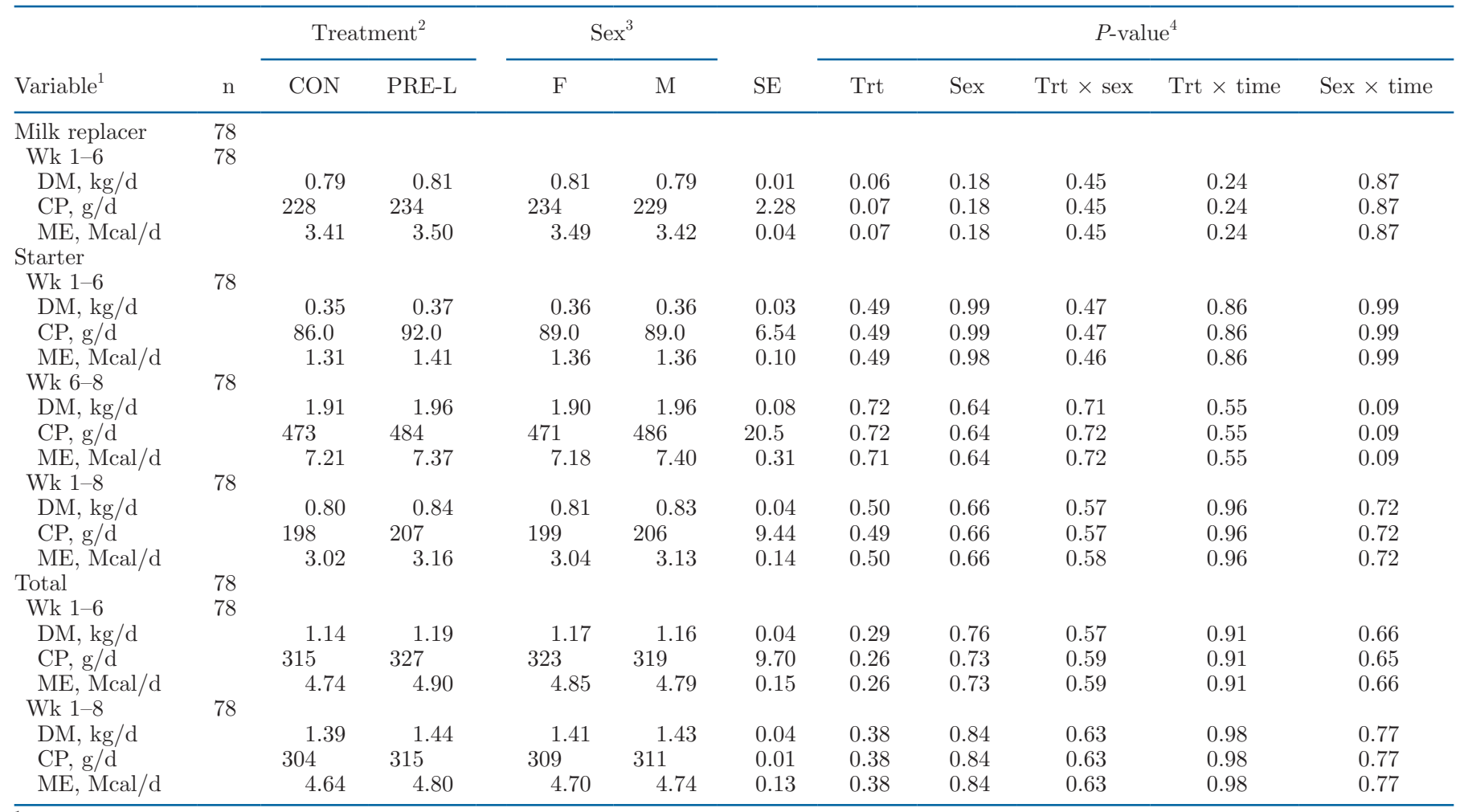

${ }^{1}$ All measurements were taken weekly.

${ }^{2}$ Calves were assigned a treatment based on dam's prepartum treatment: rumen-protected Lys (PRE-L) or control (CON).

${ }^{3}$ Calves were divided from males $(\mathrm{M})$ and females $(\mathrm{F})$ in the different treatment groups.

${ }^{4}$ Trt $\times$ sex $\times$ time interaction was not different $(P>0.50)$. Trt $=$ treatment.

site medical attention. When the calves were off-site, health scores and intakes for both MR and starter were not recorded. The DMI of cows prepartum and their colostrum measurements have been described in detail previously by Fehlberg et al. (2020). Briefly, DMI during prepartum was not different between cows in PRE-L $(12.14 \mathrm{~kg} / \mathrm{d})$ and cows in CON $(11.84 \mathrm{~kg} / \mathrm{d} ; P=0.80)$. Body weight was not different when comparing cows in PRE-L $(808 \mathrm{~kg})$ and those in CON $(803 \mathrm{~kg} ; P=0.12)$ prepartum. However, cows in PRE-L $(P=0.05)$ had a greater $\mathrm{BW}$ in the last 2 wk before calving than $\mathrm{CON}$ cows. There were no differences in colostrum yield, IgG concentration, fat, protein, or total solids $(P>0.10)$. Plasma concentration of Lys prepartum was greater for cows in PRE-L $(69.8 \mu M)$ than for cows in CON $(62.5$ $\mu M ; P=0.009)$.

\section{Diet Composition, DMI, and Growth}

The analyzed nutrients of the MR, colostrum replacer, and calf starter are in Table 1. The overall intakes of DM, CP, and ME for MR for wk 1 to 6 (MR period), wk 6 to 8 (weaning period), wk 1 to 8 (total duration on trial), and MR plus starter (total intake) for wk 1 to 6 are in Table 2. During wk 1 to 6 , calves in PRE-L tended to consume more $\mathrm{MR}(P=0.06), \mathrm{CP}$ $(P=0.07)$, and $\mathrm{ME}(P=0.07)$ than calves in CON. During wk 6 to 8 , there was a tendency for a sex $\times$ time interaction for intakes of DM, CP, and $\mathrm{ME}(P$ $=0.09)$, in which females had greater intakes on wk 6 than males, but males had greater intakes on wk 7 and 8 than females (Supplemental Figure S1, https://uofi .box.com/s/qq7ubtzvbr9wxpobczdc7fno2t108ajt).

Performance data for BW, ADG, feed efficiency (gain:feed) and growth measurements are in Table 3. Initial BW was not different between PRE-L and CON $(P=0.29)$ but there was a difference according to sex $(P<0.01)$, with males having a greater birth $\mathrm{BW}$ than females. During wk 1 to 6 , there was a tendency for a sex $\times$ time interaction $(P=0.07)$ for average $\mathrm{BW}$, where males had greater BW over wk 3 through 5 than females, but similar during wk 1, 2, and 6. Final BW and ADG during wk 1 to 6 also tended to have a treatment $\times$ sex interaction effect, where females in PRE-L $(70.5 \pm 1.2 \mathrm{~kg})$ and males in CON $(71.4 \pm 1.2 \mathrm{~kg}) \mathrm{had}$ greater final BW than females in CON $(68.9 \pm 1.2 \mathrm{~kg})$ 
Table 3. Least squares means and associated standard errors for BW, ADG, gain:feed, and stature measurements of calves throughout the experimental period

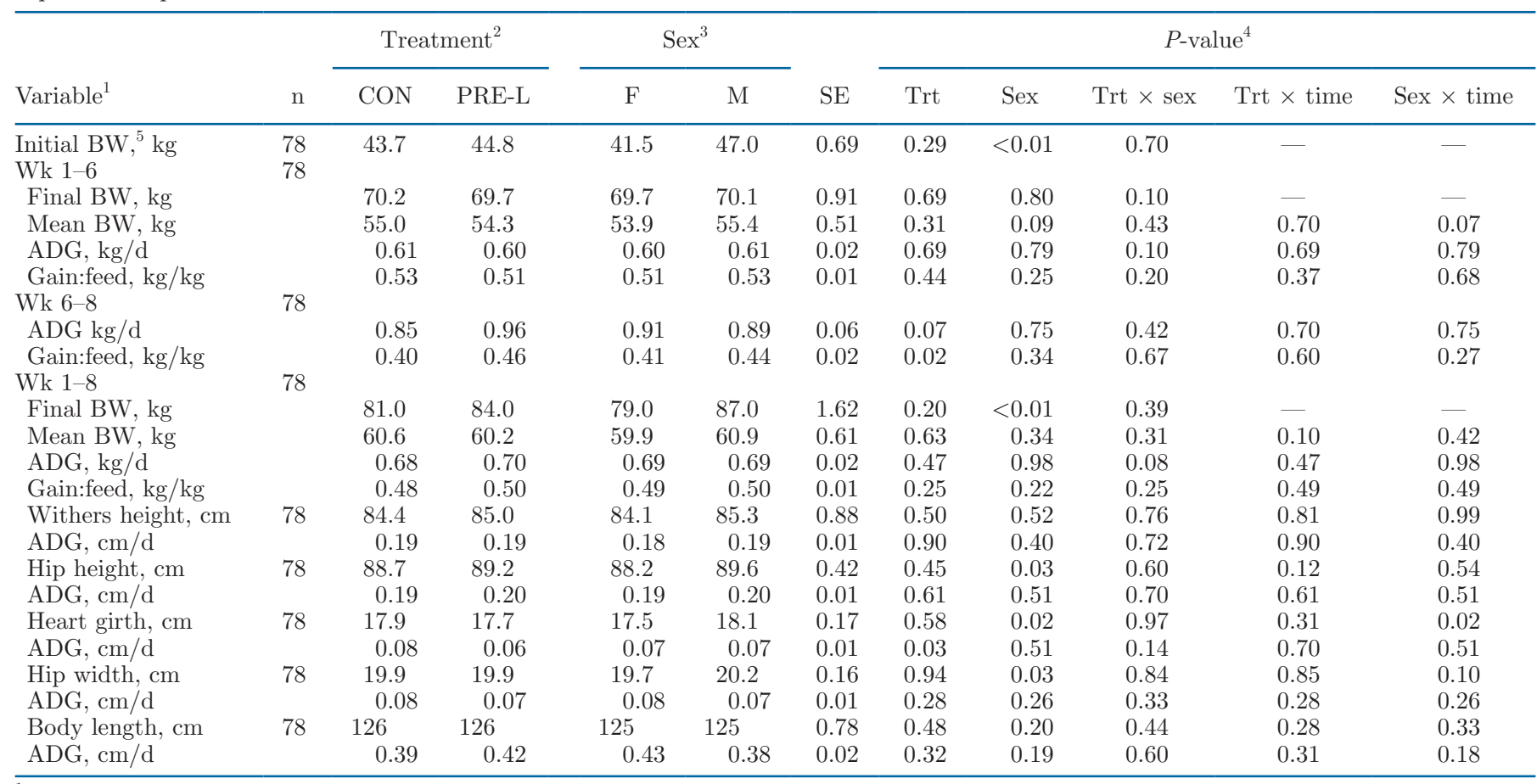

${ }^{1}$ All measurements were taken weekly.

${ }^{2}$ Calves were assigned a treatment based on dam's prepartum treatment: rumen-protected Lys (PRE-L) or control (CON).

${ }^{3}$ Calves were divided from males $(\mathrm{M})$ and females $(\mathrm{F})$ in the different treatment groups.

${ }^{4}$ Trt $\times$ sex $\times$ time interaction was not different $(P>0.26)$ except wk 1-6 mean BW $(P=0.01)$ and wk $1-8$ mean BW $(P=0.03)($ Figure 1$)$.

${ }^{5}$ Initial BW was measured at birth: $<6$ h old before colostrum.

and males in PRE-L $(68.8 \pm 1.2 \mathrm{~kg})$, and females in PRE-L $(0.62 \pm 0.03 \mathrm{~kg} / \mathrm{d})$ and males in CON $(0.64 \pm$ $0.03 \mathrm{~kg} / \mathrm{d})$ had greater ADG $(P=0.09)$ than females in CON $(0.58 \pm 0.03 \mathrm{~kg} / \mathrm{d})$ and males in PRE-L $(0.58$ $\pm 0.03 \mathrm{~kg} / \mathrm{d}$ ). During wk 6 to 8 , there was a tendency for a treatment effect $(P=0.07)$ for ADG, where calves in PRE-L gained more weight than calves in CON. Additionally, calves in PRE-L gained more weight per kilogram of feed consumed than calves in CON $(P=$ $0.02)$. There was a treatment $\times$ sex $\times$ time interaction during wk 1 to $8(P=0.03)$ for $\mathrm{BW}$, where all calves gained weight over time; however, calves in CON-M had greater BW on wk 5 and calves in CON-F had lesser BW on wk 8 (Figure 1). There was a tendency for a treatment $\times$ time interaction $(P=0.10)$ in mean $\mathrm{BW}$ for wk 1 to 8, where calves in CON weighed more than calves in PRE-L during wk 1 to 6 , but calves in PRE-L weighed more than calves in CON from wk 6 to 8 .

Male calves had greater hip heights than female calves $(P=0.03)$. There was a sex $\times$ time interaction for HG, where male calves had greater $(P=0.02) \mathrm{HG}$ in the first 3 wk of life than female calves, but similar for the rest of the period. There was also a treatment effect $(P=0.03)$ for HG ADG during the study, with

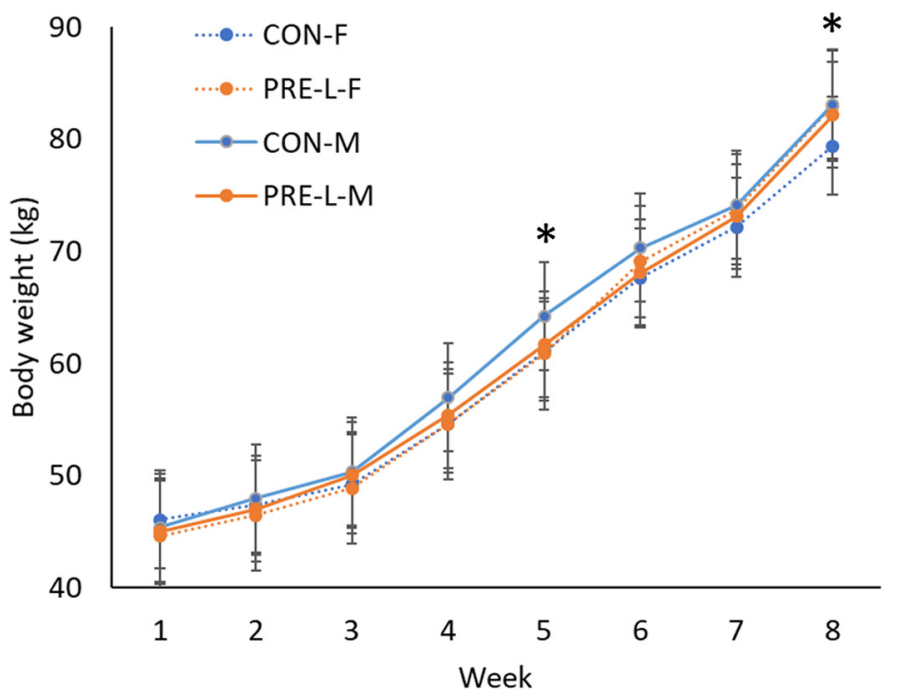

Figure 1. Least squares means $( \pm$ SEM) and associated standard errors for BW (kg) during wk 1 to 8 of dairy calves whose dams were fed rumen-protected lysine (RPL) during late gestation or not. The calves were assigned into 2 treatments based on dam's prepartum treatment: RPL supplementation (PRE-L) or without RPL (CON). They were also divided into male (M) and female (F) groups. Trt $\times$ sex $\times$ time: $P=0.03$. ${ }^{*}$ Indicates a difference between treatments at that time point at $P<0.05$. 
Table 4. Odds ratio (OR) for calves that were medicated, treated with electrolytes, or treated with antibiotics throughout the experimental period

\begin{tabular}{|c|c|c|c|c|c|c|c|}
\hline Variable & $\mathrm{n}$ & Pairwise comparison $^{1}$ & Coefficient & SEM & $\mathrm{OR}^{2}$ & $95 \% \mathrm{CI}^{3}$ & $P$-value \\
\hline Medicated $^{4}$ & & PRE-L-F - PRE-L-M & 0.56 & 0.39 & 1.75 & $0.80-3.83$ & 0.06 \\
\hline \multirow[t]{3}{*}{ Electrolytes $^{5}$} & 78 & $\mathrm{CON}-\mathrm{F}-\mathrm{CON}-\mathrm{M}$ & -0.51 & 0.43 & 0.60 & $0.25-1.42$ & 0.24 \\
\hline & & PRE-L-F - PRE-L-M & 0.19 & 0.41 & 1.21 & $0.53-2.76$ & 0.65 \\
\hline & & CON-F - PRE-L-F & -0.08 & 0.43 & 0.93 & $0.40-2.20$ & 0.87 \\
\hline \multirow{3}{*}{ Antibiotics $^{6}$} & & PRE-L-F - PRE-L-M & 1.30 & 0.59 & 3.67 & $1.13-11.90$ & 0.08 \\
\hline & & CON-F - PRE-L-F & -0.13 & 0.57 & 0.87 & $0.28-2.72$ & 0.81 \\
\hline & & CON-M - PRE-L-M & 1.31 & 0.59 & 3.69 & $1.14-12.01$ & 0.01 \\
\hline
\end{tabular}

${ }^{1}$ Calves were divided in treatment groups: control females (CON-F), lysine females (PRE-L-F), control males (CON-M), and lysine males (PREL-M). Level = yes for all pairwise comparisons; the yes indicates that, from the binary outcomes related to the variable (yes or no, for the occurrence of the event), the yes (event $=1$ ) was used in the model.

${ }^{2}$ The odds ratio (OR) indicates the probability of being medicated (anti-inflammatory, antimicrobials, electrolytes, and vitamin B complex administration, combined or not), of receiving electrolytes, or receiving antibiotics in male (M) and female (F) calves from cows who received rumen-protected Lys (PRE-L) during prepartum or not $(\mathrm{CON})$. If the OR is $>1$, a given factor (sex of the calves or prepartum diet of the dam) in the comparison is more likely to have occurrence of being medicated, receiving electrolytes, or receiving antibiotics than the other by a factor of the difference above. If the OR is $<1$, a given factor has a lower probability of occurrence than the other.

${ }^{3} \mathrm{CI}=$ confidence interval derived from binomial regression.

${ }^{4}$ Medications are both electrolytes and antibiotics given to calves when illnesses arise.

${ }^{5}$ When scouring (fecal >2), $100 \mathrm{~g}$ of electrolytes (Diaque, Boehringer Ingelheim) was given orally and $5 \mathrm{~mL}$ of vitamin B complex (Vitamin B complex HP, Vet One) was given intramuscularly.

${ }^{6}$ If scouring was severe, $6 \mathrm{~mL}$ of penicillin (Combi-Pen-48, Bimeda, Inc.) was given intramuscularly. If calves showed signs of respiratory disease (score $>2$ ), $2 \mathrm{~mL}$ of tulathromycin (Draxxin, Zoetis) was given subcutaneously.

calves in CON having greater measurements of HG per day than calves in PRE-L.

\section{Health}

Female calves in PRE-L tended to be more likely [odds ratio $(\mathbf{O R})=1.75,95 \% \mathrm{CI}=0.80-3.83 ; P=$ 0.06 , Table 4] to be medicated than male calves in PRE-L during the first 8 wk of life. Male calves in CON were more likely $(\mathrm{OR}=2.80,95 \% \mathrm{CI}=1.27-6.19, P$ $=0.01)$ to be medicated than male calves in PRE-L.
When analyzing the odds of receiving antibiotics only, female calves in PRE-L tended $(\mathrm{OR}=3.67,95 \% \mathrm{CI}=$ $1.13-11.90, P=0.08)$ to be more likely to receive antibiotic than male calves in PRE-L, and male calves in CON were more likely to receive antibiotics than male calves in PRE-L $(\mathrm{OR}=3.69,95 \% \mathrm{CI}=1.14-12.01, P$ $=0.01)$. Calves in CON tended to have more days being treated with antibiotics only $(P=0.10)$ and medicated (antibiotics plus electrolytes; $P=0.08$ ) than calves in PRE-L (Table 5). Calves in CON-F tended to be less likely $(\mathrm{OR}=0.58,95 \% \mathrm{CI}=0.30-1.11 ; P=0.09)$ to

Table 5. Least squares means for days that calves were treated with medication, electrolytes, or antibiotics throughout the experimental period

\begin{tabular}{|c|c|c|c|c|c|c|c|c|c|}
\hline Variable $^{1}$ & $\mathrm{n}$ & \multicolumn{2}{|c|}{ Treatment $^{2}$} & \multicolumn{2}{|c|}{$\operatorname{Sex}^{3}$} & $\mathrm{SE}$ & \multicolumn{3}{|c|}{$P$-value } \\
\hline $\begin{array}{l}\text { Medicated }^{4} \\
\text { Electrolytes } \\
\text { Antibiotics }^{6}\end{array}$ & $\begin{array}{l}78 \\
78 \\
78\end{array}$ & $\begin{array}{l}6.2 \\
4.4 \\
5.6\end{array}$ & $\begin{array}{l}4.7 \\
4.4 \\
4.2\end{array}$ & $\begin{array}{l}5.1 \\
3.9 \\
4.3\end{array}$ & $\begin{array}{l}5.7 \\
4.9 \\
5.4\end{array}$ & $\begin{array}{l}0.6 \\
0.4 \\
0.6\end{array}$ & $\begin{array}{l}0.08 \\
0.98 \\
0.10\end{array}$ & $\begin{array}{l}0.56 \\
0.11 \\
0.24\end{array}$ & $\begin{array}{l}0.24 \\
0.58 \\
0.87\end{array}$ \\
\hline
\end{tabular}

${ }^{1}$ All measurements were taken weekly.

${ }^{2}$ Calves were assigned a treatment based on dam's prepartum treatment: rumen-protected Lys (PRE-L) or control (CON).

${ }^{3}$ Calves were divided from males $(\mathrm{M})$ and females $(\mathrm{F})$ in the different treatment groups.

${ }^{4}$ Medications are both electrolytes and antibiotics given to calves when health illnesses arise.

${ }^{5}$ When scouring (fecal >2), $100 \mathrm{~g}$ of electrolytes (Diaque, Boehringer Ingelheim) was given orally and $5 \mathrm{~mL}$ of vitamin B complex (Vitamin B complex HP, Vet One) was given intramuscularly.

${ }^{6}$ If scouring is severe, $6 \mathrm{~mL}$ of penicillin (Combi-Pen-48, Bimeda Inc.) was given intramuscularly. If calves showed signs of respiratory disease (respiratory score > 2), $2 \mathrm{~mL}$ of tulathromycin (Draxxin, Zoetis) was given subcutaneously. 
have fecal scores $<2$ than calves in CON-M. No differences were detected for the likelihood of having high temperature $(P=0.44)$.

\section{Serum Chemistry Profile, Plasma AA, and Metabolites}

Serum chemistry profiles are in Table 6 . There was a tendency for a treatment $\times$ sex interaction for anion gap $(P=0.09)$, where calves in PRE-L-M had a smaller anion gap $(16.74 \pm 0.44 \mathrm{mEq} / \mathrm{L})$ than calves in CON-M $(17.99 \pm 0.44 \mathrm{mEq} / \mathrm{L})$, calves in CON-F $(17.46 \pm 0.44 \mathrm{mEq} / \mathrm{L})$, and calves in PRE-L-F $(17.41 \pm$ $0.44 \mathrm{mEq} / \mathrm{L})$. There was an effect of sex $(P=0.03)$ on the bicarbonate concentration, with male calves having greater bicarbonate concentration in blood than female calves. There was a tendency for a treatment $\times$ sex interaction effect $(P=0.06)$ in which calves in CON-F $(4.59 \pm 0.08 \mathrm{~g} / \mathrm{dL})$ had lesser serum TP than calves in PRE-L-F $(4.83 \pm 0.08 \mathrm{~g} / \mathrm{dL})$, calves in CON-M $(5.02 \pm$ $0.08 \mathrm{~g} / \mathrm{dL})$, and calves in PRE-L-M $(4.81 \pm 0.08 \mathrm{~g} / \mathrm{dL})$. There was a tendency for a treatment $\times$ sex interaction for Ca concentration $(P=0.10)$, where calves in CON$\mathrm{M}(11.05 \pm 0.13 \mathrm{mg} / \mathrm{dL})$ had greater Ca concentration than male calves in PRE-L-M $(10.71 \pm 0.13 \mathrm{mg} / \mathrm{dL})$, calves in CON-F $(10.72 \pm 0.13 \mathrm{mg} / \mathrm{dL})$, and calves in PRE-L-F $(10.79 \pm 0.13 \mathrm{mg} / \mathrm{dL})$. There was a treatment $\times$ sex interaction for serum $\mathrm{P}$ concentration $(P$ $=0.05)$, where calves in CON-M $(7.32 \pm 0.13 \mathrm{mg} / \mathrm{dL})$ had greater $\mathrm{P}$ than calves in PRE-L-M $(6.96 \pm 0.13$ $\mathrm{mg} / \mathrm{dL})$, calves in CON-F $(7.07 \pm 0.13 \mathrm{mg} / \mathrm{dL})$, and calves in PRE-L-F $(7.18 \pm 0.13 \mathrm{mg} / \mathrm{dL})$. There was a tendency for a treatment $\times$ sex interaction for $\mathrm{Cl}$ $(P=0.10)$, in which calves in PRE-L-F $(98.05 \pm 0.66$ $\mathrm{mmol} / \mathrm{L})$ had greater concentration of $\mathrm{Cl}$ than calves in CON-F (96.66 $\pm 0.66 \mathrm{mmol} / \mathrm{L})$ and calves in PRE$\mathrm{L}-\mathrm{M}(96.80 \pm 0.66 \mathrm{mmol} / \mathrm{L})$, but similar than calves in CON-M $(97.49 \pm 0.66 \mathrm{mmol} / \mathrm{L})$. There was a tendency for a treatment $\times$ sex interaction for $\operatorname{GGT}(P=0.07)$, where calves in PRE-L-M $(341 \pm 32.8 \mathrm{IU})$ had lesser GGT than calves in CON-M $(371 \pm 32.8 \mathrm{IU})$, calves in CON-F (364 $\pm 32.8 \mathrm{IU})$, and calves in PRE-L-F (369 \pm $32.8 \mathrm{IU})$. There was a tendency for a treatment effect on the TB concentration $(P=0.06)$, where calves in CON had greater TB than calves in PRE-L. There was a sex effect $(P=0.01)$ for ALP, with female calves having greater concentration of ALP than male calves.

Plasma concentrations of AA and metabolites are in Table 7 . There was a treatment $\times$ sex interaction for total AA (TAA; $P=0.03$, Figure 2), where calves in PRE-L-M and CON-F $(2,916 \pm 112 \mu M$ and $2,848 \pm$ $112 \mu M$, respectively) had greater TAA concentrations than calves in PRE-L-F and CON-M $(2,684 \pm 112 \mu M$ and $2,582 \pm 112 \mu M$, respectively). There was a treat- ment $\times$ sex interaction for total dispensable AA $(P=$ 0.01 , Figure 2), where calves in CON-F and in PRE-L$\mathrm{M}$ had greater concentrations of total dispensable AA $(1,179 \pm 51.7 \mu M$ and $1,188 \pm 51.7 \mu M)$ than calves in PRE-L-F and in CON-M $(1,062 \pm 51.7 \mu M$ and 1,031 $\pm 51.7 \mu M)$. There was a treatment $\times$ sex interaction for total branched-chain AA $(P=0.04$, Figure 2$)$ where calves in PRE-L-M and CON-F $(272.0 \pm 14.5$ $\mu M$ and $267.1 \pm 14.5 \mu M$, respectively) had greater total branched-chain AA concentrations than calves in PRE-L-F and CON-M $(236.0 \pm 14.5 \mu M$ and $246.8 \pm$ $14.5 \mu M$, respectively). There was a treatment $\times$ sex interaction for total sulfur AA $(P=0.04$, Figure 2), where calves in CON-M $(232.7 \pm 11.7 \mu M)$ had lesser total sulfur AA concentration in plasma than calves in PRE-L-M $(264.7 \pm 11.7 \mu M)$, calves in CON-F (273.7 $\pm 11.7 \mu M)$, and calves in PRE-L-F $(253.9 \pm 11.7 \mu M)$. There was a sex difference for His $(P=0.04)$, where male calves had greater concentration of plasma His than female calves. There was a treatment $\times$ sex interaction for Ile $(P=0.03)$, where CON-F and PRE-L-M $(80.1 \pm 4.8 \mu M$ and $80.5 \pm 4.8 \mu M$, respectively) had greater concentration than PRE-L-F and CON-M (71.1 $\pm 4.8 \mu M$ and $71.1 \pm 4.8 \mu M$, respectively). There was a treatment $\times$ sex interaction for plasma concentration of Lys as a percentage of TAA ( $P=0.04$, Figure 2), where calves in PRE-L-F and CON-M (4.09 $\pm 0.11 \%$ and $4.16 \pm 0.11 \%$, respectively) had greater percentage compared with calves in CON-F and PRE-L-M (3.91 $\pm 0.11 \%$ and $3.90 \pm 0.11 \%$, respectively). There was a tendency for a sex $\times$ time effect $(P=0.10)$ for Met, with an increase overtime on the plasma concentrations of Met for female calves and a decrease overtime for male calves. Plasma concentrations of Phe tended to be greater $(P=0.07)$ for calves in PRE-L than for calves in CON. There was a treatment $\times$ sex interaction for Thr and Val $(P=0.04$, Figure 2$)$, where calves in PRE-L-M had greater concentrations of Thr and Val in plasma $(318.1 \pm 18.8$ and $37.8 \pm 2.0 \mu M$, respectively) than other calves (CON-F: $304.3 \pm 18.8$ and $35.2 \pm 2.0 \mu \mathrm{M}$; PRE-L-M: $270.1 \pm 18.8$ and 33.3 $\pm 2.0 \mu M$; CON-M: $274.1 \pm 18.8$ and $30.6 \pm 2.0 \mu M$ ). There was a treatment $\times$ sex interaction for Ala $(P=$ $0.04)$ and Cys $(P=0.01$, Figure 2$)$ plasma concentrations, where calves in CON-M $(4.4 \pm 1.1 \mu M$ and 171.6 $\pm 9.7 \mu M$, respectively) had lesser Ala and Cys than calves in PRE-L-M $(7.2 \pm 1.1 \mu M$ and $200.0 \pm 9.7$ $\mu M$, respectively), calves in CON-F $(6.5 \pm 1.1 \mu M$ and $210.2 \pm 9.7 \mu M$, respectively), and calves in PRE-L$\mathrm{F}(5.2 \pm 1.1 \mu M$ and $191.5 \pm 9.7 \mu M$, respectively). Calves in PRE-L tended to have $(P=0.07)$ greater plasma concentration of Gln than calves in CON. Male calves in CON had lesser $(P=0.01$, Figure 2$)$ plasma concentration of Glu $(39.1 \pm 2.9 \mu M)$ and Gly (99.9 
$\pm 7.4 \mu M)$ than calves in PRE-L-M $(51.2 \pm 2.9 \mu M$ and $133.2 \pm 7.4 \mu M$, respectively), calves in CON-F (53.7 $\pm 2.9 \mu M$ and $141.7 \pm 7.4 \mu M$, respectively), and calves in PRE-L-F $(46.2 \pm 2.9 \mu M$ and $129.9 \pm 7.4 \mu M$, respectively). Calves in PRE-L-F had lesser concentrations of Ser $(P=0.05$, Figure $2 ; 310.6 \pm 27.6 \mu M)$ than calves in CON-F $(372.5 \pm 27.6 \mu M)$, calves in CON-M $(364.4 \pm 27.6 \mu M)$, and calves in PRE-L-M (400.1 \pm $27.6 \mu M)$. Male calves in CON $(114.55 \pm 8.20 \mu M)$ had lesser plasma concentration of the metabolite citrulline $(P=0.02$, Figure 2$)$ than calves in PRE-L-M (137.39 $\pm 8.20 \mu M)$, calves in CON-F $(143.80 \pm 8.20 \mu M)$, and calves in PRE-L-F $(129.00 \pm 8.20 \mu M)$.

\section{Phagocytosis and Oxidative Burst}

Phagocytosis and oxidative burst in neutrophils and monocytes are in presented in Table 8. Calves in PRE-L tended $(P=0.08)$ to have greater percentage of phagocytic neutrophils than calves in CON. Phagocytosis in neutrophils increased from $\mathrm{d} 0$ to 7 but decreased on $\mathrm{d}$ $14(P=0.001)$ and increased in monocytes over time $(P=0.03)$. Oxidative burst in neutrophils increased over time $(P=0.03)$, whereas it decreased over time in monocytes $(P=0.005)$. There was a tendency for the CD8 cells to decrease over time $(P=0.10)$. The number of $\gamma \delta \mathrm{T}$ cells increased over time $(P=0.01)$.

Table 6. Least squares means and associated standard errors for blood metabolites of calves throughout the experimental period ${ }^{1}$

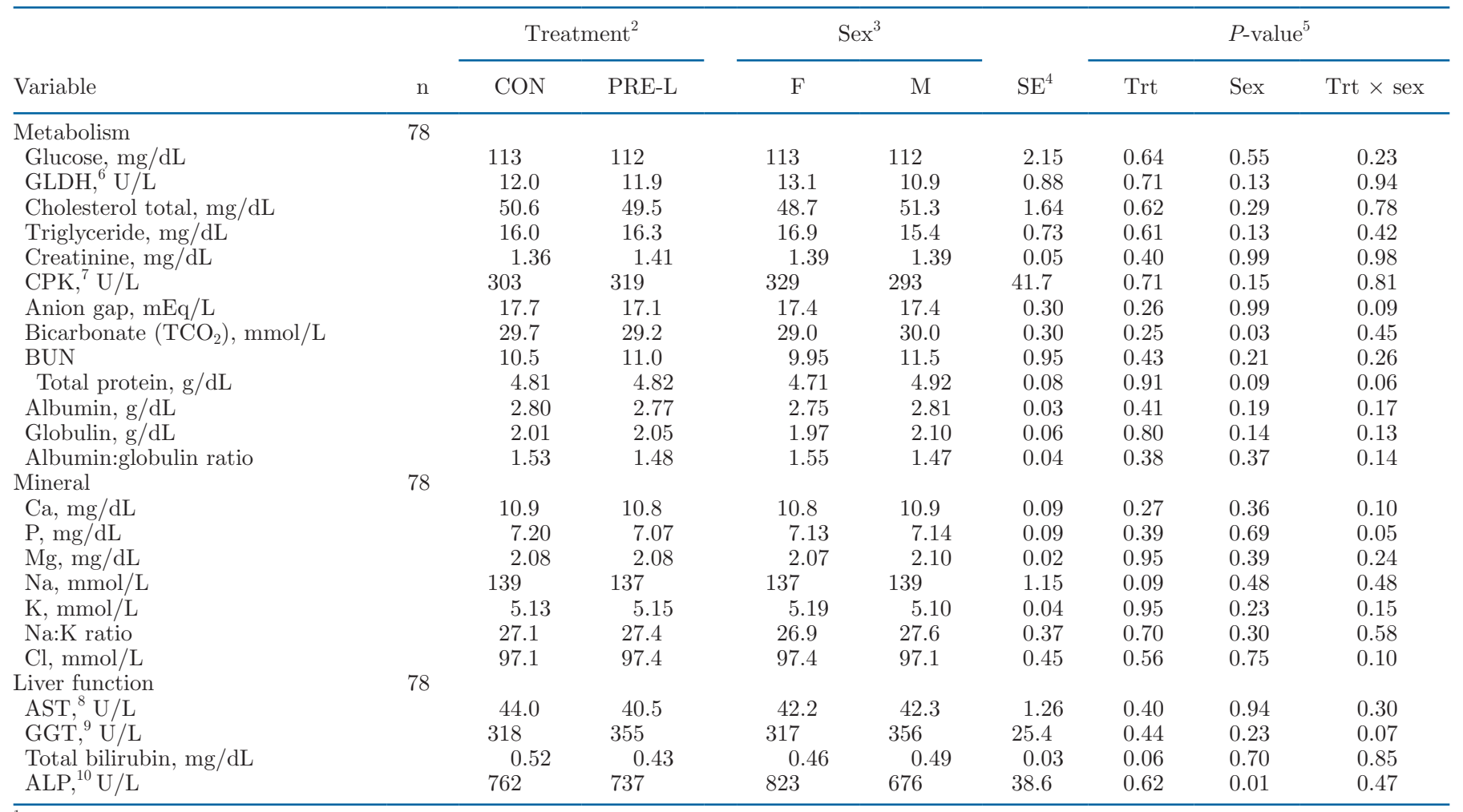

${ }^{1}$ Blood samples were collected at d 0,2, 7, 14, and 28 of age.

${ }^{2}$ Calves were assigned a treatment based on dam's prepartum treatment: Lys (PRE-L) or control (CON).

${ }^{3}$ Calves were divided from males (M) and females (F) in the different treatment groups.

${ }^{4}$ Greatest value for standard error of the mean within treatment.

${ }^{5}$ Trt $\times$ sex $\times$ time interaction was not different $(P>0.15)$; Trt $\times$ time interaction was not different $(P>0.22)$; sex $\times$ time interaction was not different $(P>0.15)$ except for creatinine $(P<0.0001)$; time effect was all different $(P<0.03)$ except for sodium $(P=0.15)$, Na:K ratio $(P=$ $0.13)$, and total bilirubin $(P=0.51)$.

${ }^{6}$ Glutamate dehydrogenase.

${ }^{7}$ Creatine phosphokinase.

${ }^{8}$ Aspartate aminotransferase.

${ }^{9}$ Gamma-glutamyl transpeptidase.

${ }^{10}$ Alkaline phosphatase total. 
Table 7. Least squares means and associated standard errors for plasma AA $(\mu M)$ of calves throughout the experimental period

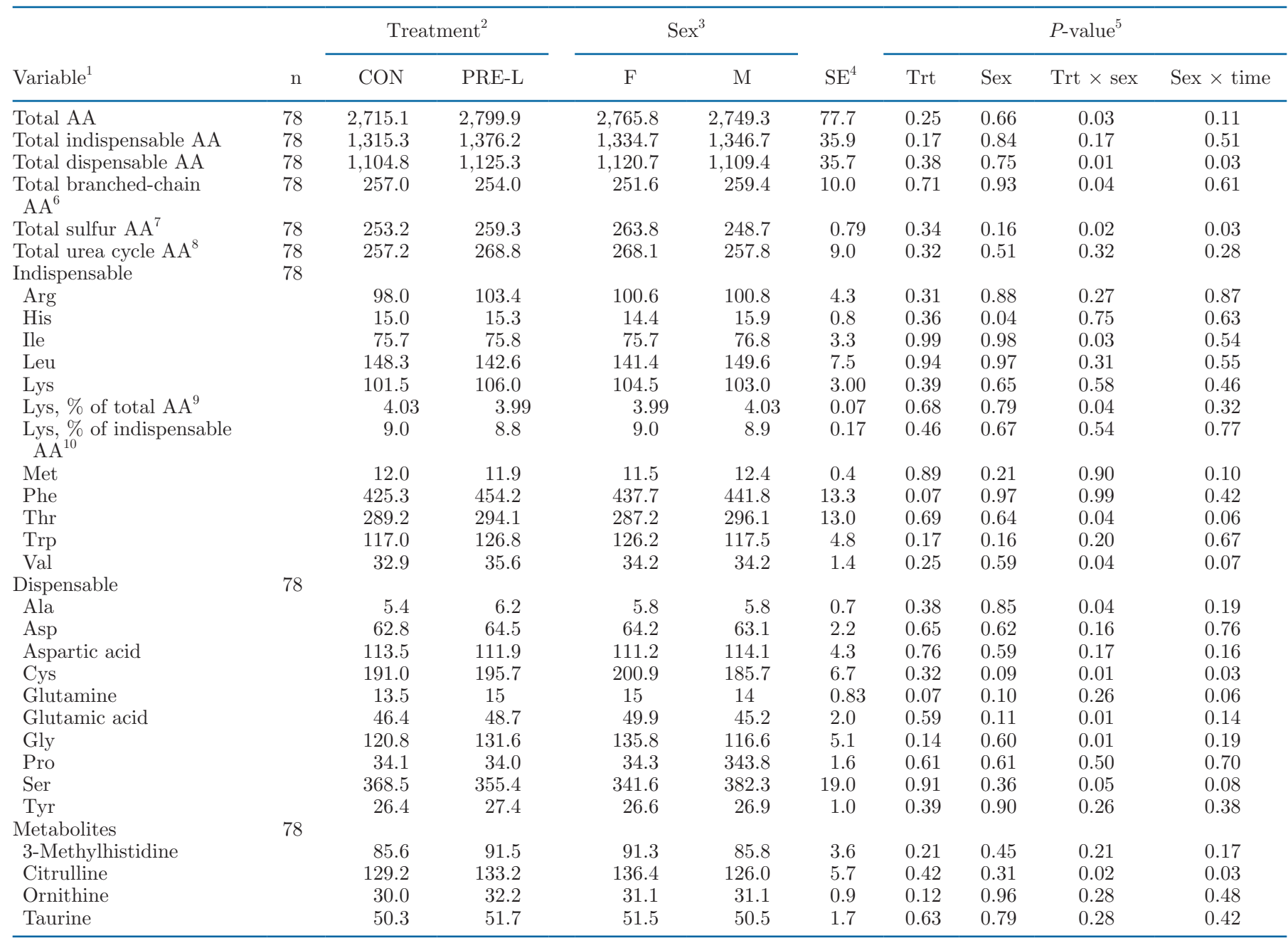

${ }^{1}$ Data were collected at $\mathrm{d} 0,7$, and 14 of age.

${ }^{2}$ Calves were assigned a treatment based on dam's prepartum treatment: Lys (PRE-L) or control (CON).

${ }^{3}$ Calves were divided from males $(\mathrm{M})$ and females $(\mathrm{F})$ in the different treatment groups.

${ }^{4}$ Greatest value for standard error of the mean within treatment.

${ }^{5}$ Trt $\times$ sex $\times$ time interaction was not different $(P>0.11)$ except for glutamic acid $(P=0.03)$ and taurine $(P=0.02)$; trt $\times$ time interaction was not different $(P>0.21)$ except for a tendency with alanine $(P=0.06)$; time effect was all different $(P<0.007)$ except for methionine $(P$ $=0.51)$ and tyrosine $(P=0.61)$.

${ }^{6}$ Total branched $\mathrm{AA}=\mathrm{Ile}$, Leu, and Val.

${ }^{7}$ Total sulfur $\mathrm{AA}=$ Met, taurine, and Cys.

${ }^{8}$ Total urea cycle $\mathrm{AA}=\mathrm{Arg}$, citrulline, and ornithine.

${ }^{9}$ Lys as a $\%$ of total AA $=$ Lys $(\mu M) /[\operatorname{total} \mathrm{AA}(\mu M)-$ Lys $(\mu M)]$.

${ }^{10}$ Lys as a $\%$ of total indispensable AA $=$ Lys $(\mu M) /[$ total indispensable AA $(\mu M)-$ Lys $(\mu M)]$.

\section{DISCUSSION}

The objective of this study was to determine effects of RPL fed to cow prepartum and the sex of calves on the performance, health, plasma AA, and metabolite concentrations of their calves during the first $56 \mathrm{~d}$ of life. Our hypothesis was that RPL supplemented during the prepartum period would not only benefit cow performance but might also benefit growth and devel- opment of the calves due to a greater in utero transfer of Lys and other IAA.

\section{Diet Composition, DMI, and Growth}

Diets fed to cows prepartum have been shown to influence growth, development, and intakes of their calves (Alharthi et al., 2018; Haisan et al., 2019). These findings are in agreement with the present study, as calves 
A

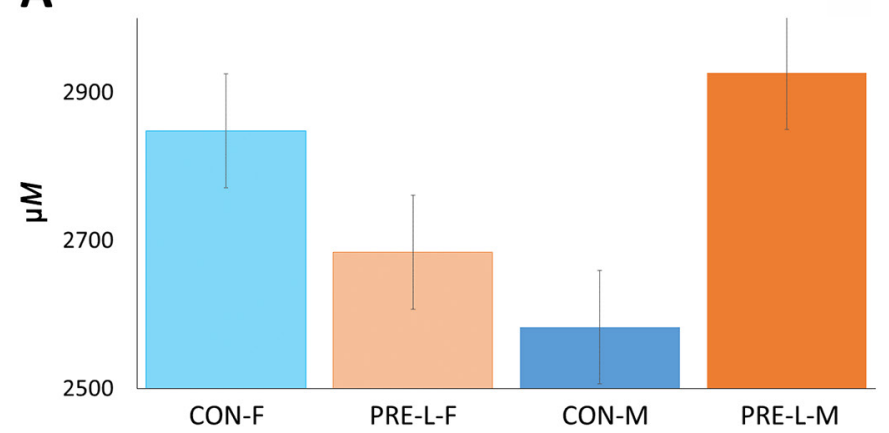

B

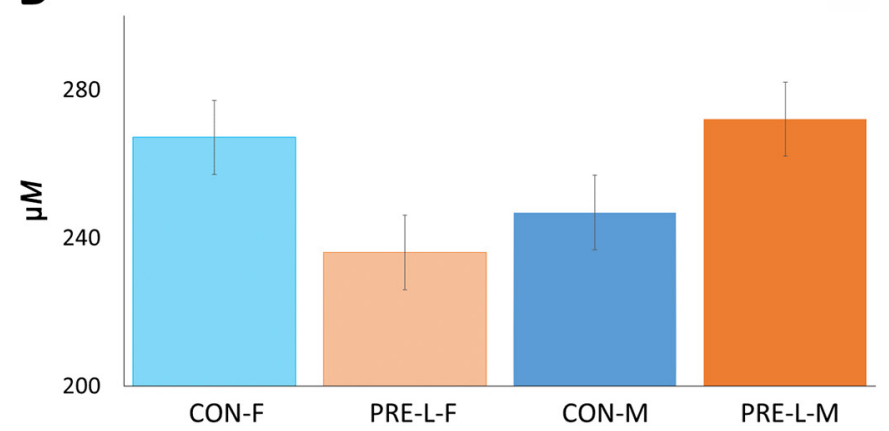

C

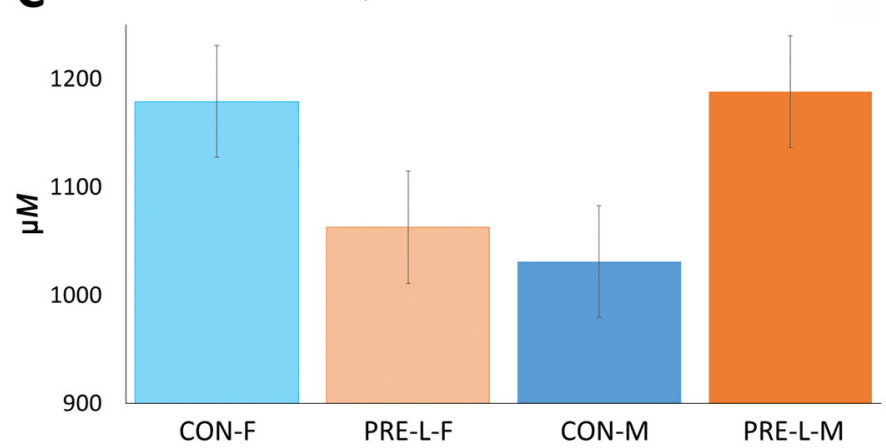

D

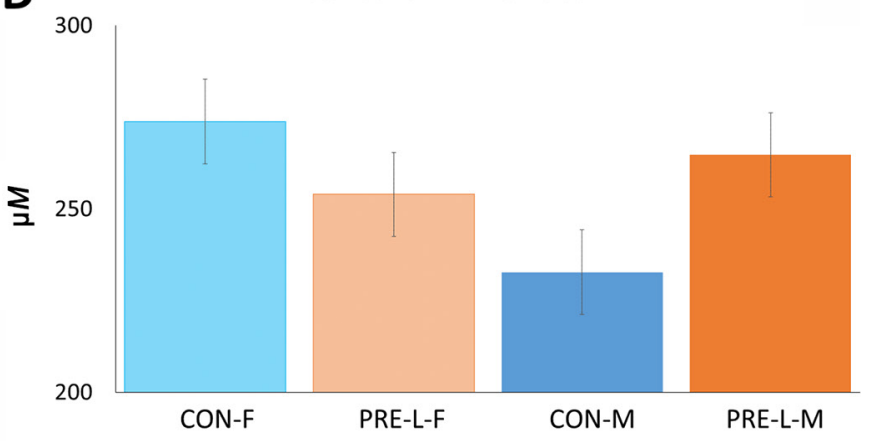

$\mathbf{E}$

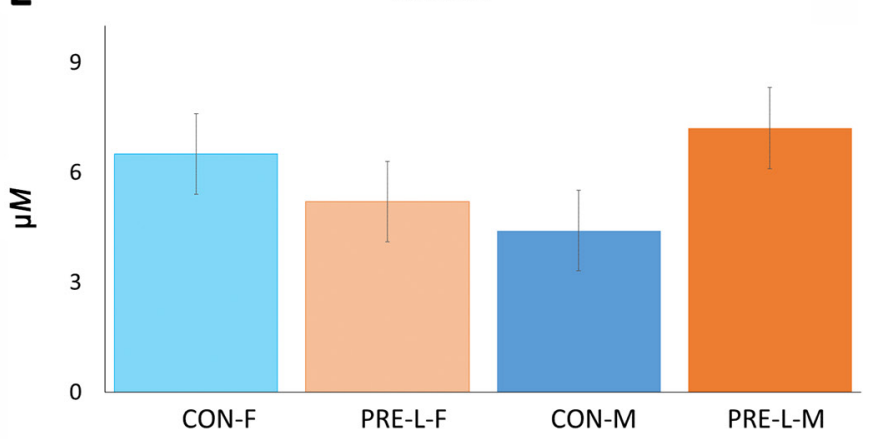

$\mathbf{F}$

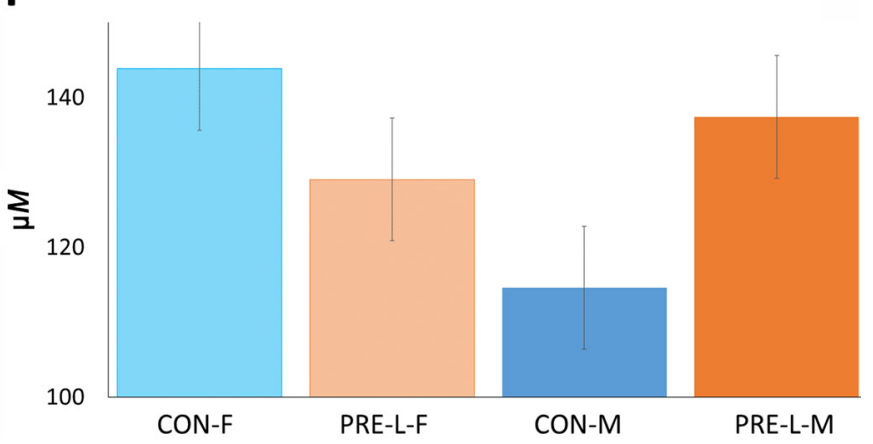

Figure 2. Effects of maternal feeding of rumen-protected lysine (RPL) and sex on plasma AA and metabolites ( $\mu M$ ) of dairy calves. (A) Total plasma AA; (B) total branched-chain AA; (C) total dispensable AA; (D) total sulfur AA; (E) alanine; (F) citrulline; (G) cystine; (H) glutamic acid; (I) glycine; $(\mathrm{J})$ isoleucine; $(\mathrm{K})$ Lys as a percentage of total AA; (L) serine; $(\mathrm{M})$ threonine; (N) = valine. Interaction of treatment $\times$ sex: $P \leq 0.05$. Error bars are standard errors of the least squares means. PRE-L $=$ treatment with RPL supplementation; CON $=$ control; $\mathrm{M}=$ male; $\mathrm{F}=$ female.

within the PRE-L group refused less MR during their first $6 \mathrm{wk}$ of life, resulting in a tendency for a greater intake of DM, CP, and ME. During what can be considered as the preweaning period, or from wk 6 to 8 , calves in PRE-L tended to gain more weight than calves in CON, which is likely a result of a concomitant greater feed efficiency, as calves in PRE-L gained more weight per kilogram of feed consumed. The supplementation of maternal diet during late gestation with IAA was already reported to have an effect over the neonatal calf performance and immune response (Jacometo et al., 2016; Alharthi et al., 2018; Jacometo et al., 2018; Abuelo, 2020). For instance, rumen-protected Met fed to dairy cows during prepartum exerted fetal programming effects due to changes in placental metabolism (Batistel et al., 2019). In the same way, it is likely that the RPL fed to cows prepartum could trigger metabolic signatures in the uteroplacental tissue, improving the placental transport of nutrients to the fetus. However, how these mechanisms function and the role of Lys 
G

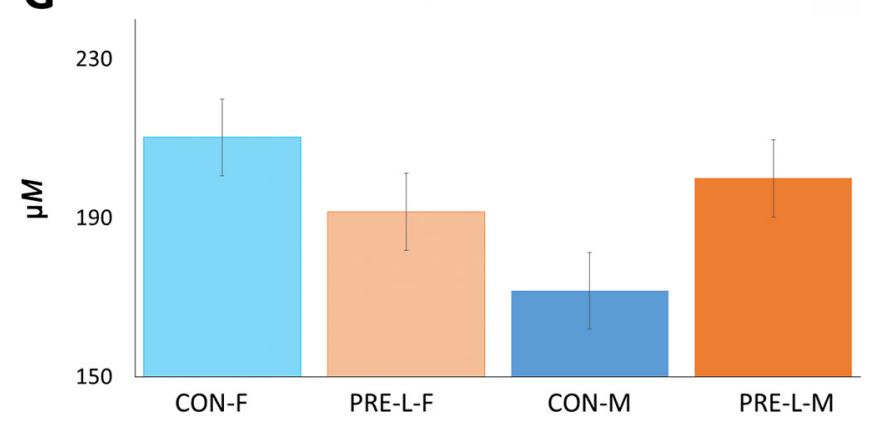

H

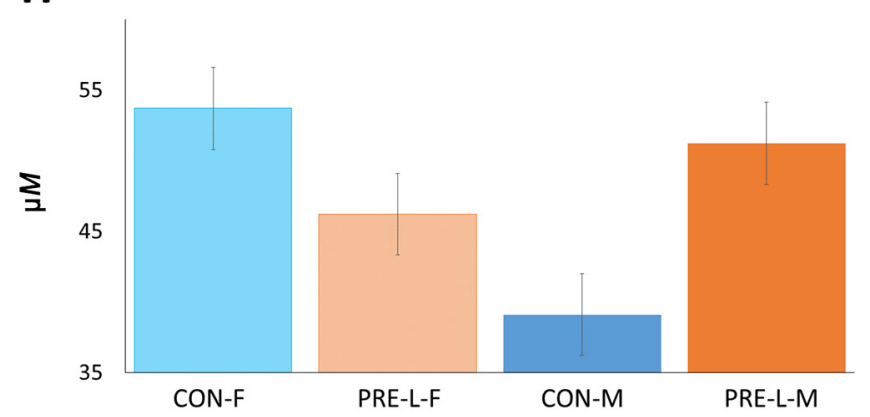

I

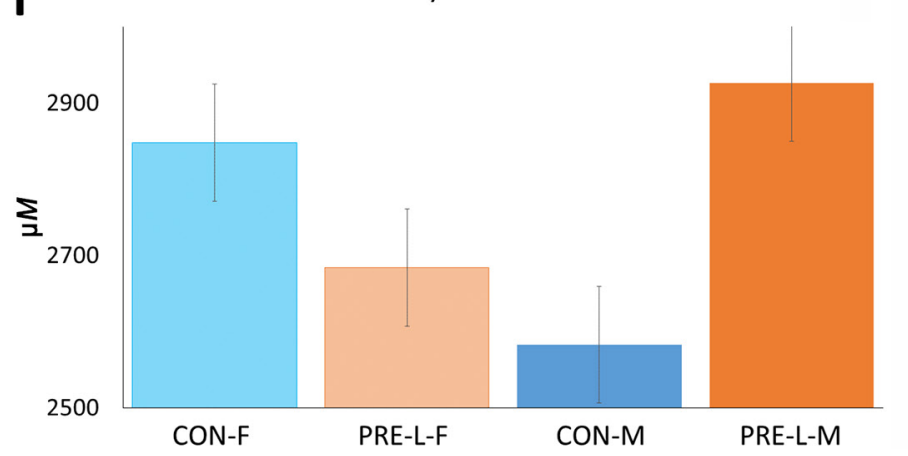

J

Isoleucine

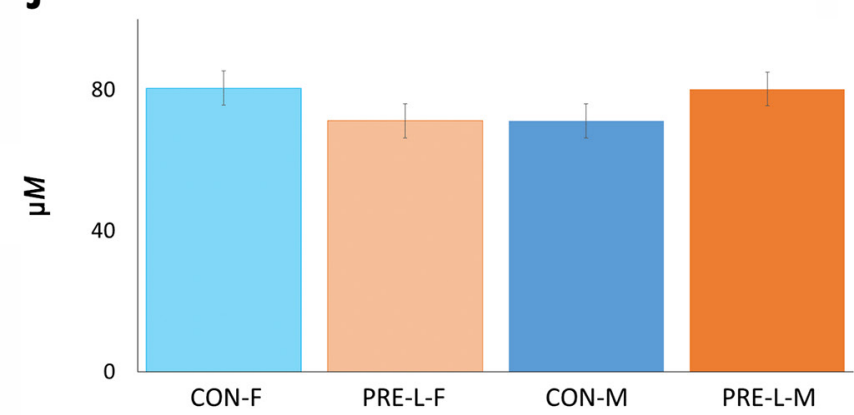

K

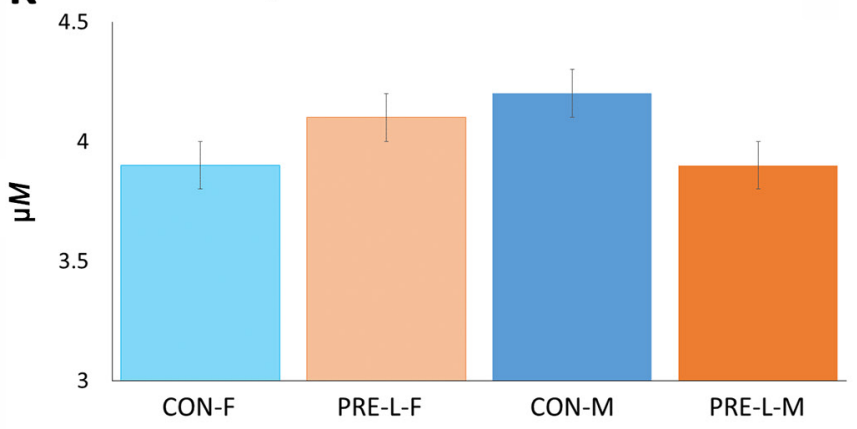

L

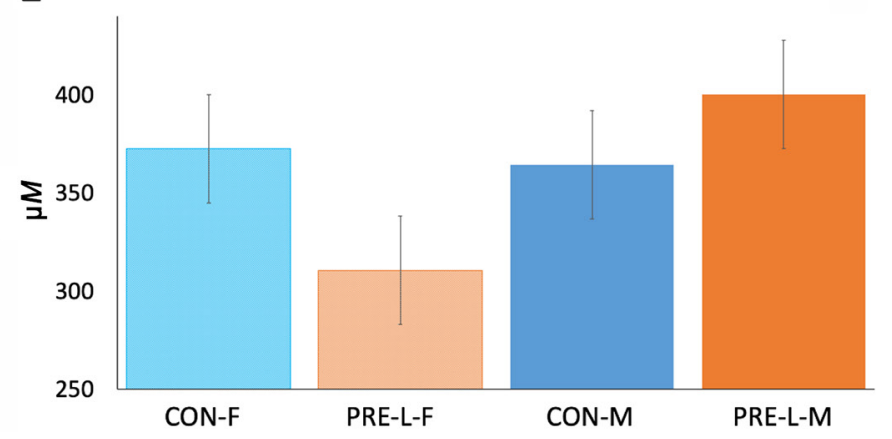

Figure 2 (Continued). Effects of maternal feeding of rumen-protected lysine (RPL) and sex on plasma AA and metabolites ( $\mu M$ ) of dairy calves. (A) Total plasma AA; (B) total branched-chain AA; (C) total dispensable AA; (D) total sulfur AA; (E) alanine; (F) citrulline; (G) cystine; $(\mathrm{H})$ glutamic acid; (I) glycine; $(\mathrm{J})$ isoleucine; $(\mathrm{K})$ Lys as a percentage of total AA; $(\mathrm{L})$ serine; $(\mathrm{M})$ threonine; $(\mathrm{N})=$ valine. Interaction of treatment $\times$ sex: $P \leq 0.05$. Error bars are standard errors of the least squares means. PRE-L $=$ treatment with RPL supplementation; CON $=$ control; $\mathrm{M}=$ male $; \mathrm{F}=$ female.

on placental tissue remain unclear; hence, the importance of future work in evaluating the Lys effects on the placenta. Additionally, there were no differences in starter intakes between calves from the cows treated with or without supplemental RPL, probably because consumption of starter is normally minimal in the first 2 to 3 wk of life (Drackley, 2008).

The greater $\mathrm{HG}$ for male calves in comparison with female calves is likely a consequence of male calves growing faster and larger than female calves (Govoni et al., 2003). Rumen-protected Lys fed during prepartum did not affect the calves' initial BW or BW gains. Although this is the first study evaluating the effects of feeding RPL during late gestation on offspring development, variable results are reported regarding maternal nutrition in late gestation and subsequent calf development. Dunn et al. (2017) reported that there were no differences in BW or BW gain between calves from cows fed grass silage only or grass silage plus concentrate during the prepartum period. Conversely, Martin et al. (2007) reported no difference in calf birth weight, although weaning BW tended to be greater for female calves from 

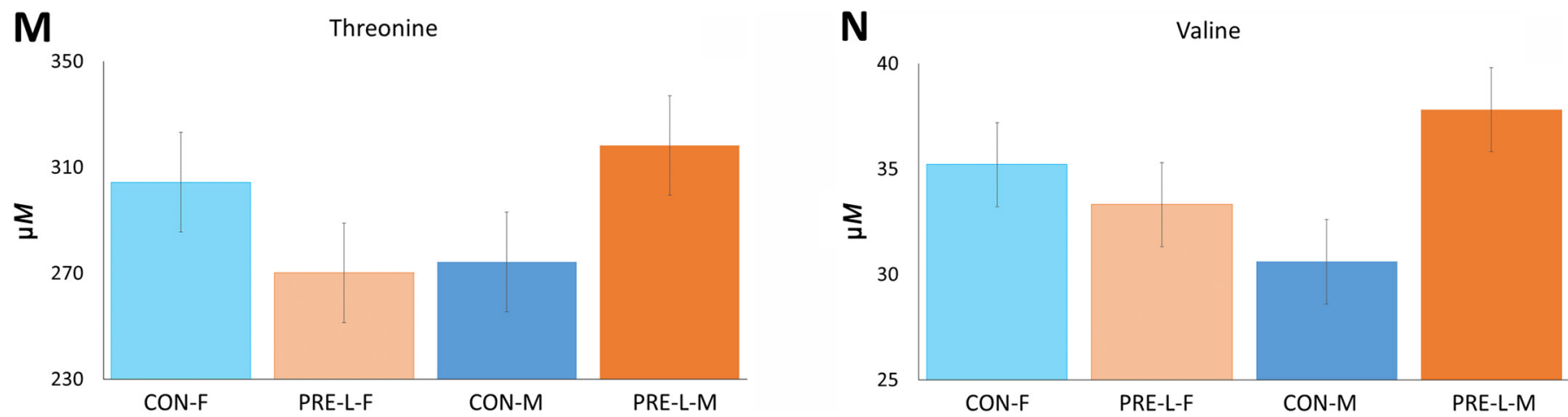

Figure 2 (Continued). Effects of maternal feeding of rumen-protected lysine (RPL) and sex on plasma AA and metabolites ( $\mu M$ ) of dairy calves. (A) Total plasma AA; (B) total branched-chain AA; (C) total dispensable AA; (D) total sulfur AA; (E) alanine; (F) citrulline; (G) cystine; $(\mathrm{H})$ glutamic acid; (I) glycine; $(\mathrm{J})$ isoleucine; $(\mathrm{K})$ Lys as a percentage of total AA; $(\mathrm{L})$ serine; $(\mathrm{M})$ threonine; $(\mathrm{N})=$ valine. Interaction of treatment $\times$ sex: $P \leq 0.05$. Error bars are standard errors of the least squares means. PRE-L $=$ treatment with RPL supplementation; CON $=$ control; $\mathrm{M}=$ male; $\overline{\mathrm{F}}=$ female.

grazing beef cows that received a protein concentrate $(0.45 \mathrm{~kg} / \mathrm{d}$ or a $42 \% \mathrm{CP})$ during late gestation. Previously, Beaty et al. (1994) had also reported increased calf weaning weight in response to increased CP supply to the dam during late gestation. However, results from studies with grazing beef cows require specific interpretation and need to be cautiously interpreted when compared with dairy cows fed conserved forages due to differences in ruminal environment leading to altered fiber fermentation patterns (Holden et al., 1994; Bargo et al., 2001). Additionally, in some cases it is possible that CP supplementation acts more as a complement for the dam's diet because nutritional requirements of pregnant beef cows could exceed the nutritional value of the grazed dormant pasture. Furthermore, there are reports supporting the hypothesis that a calf's birth BW and BW gain are affected upon a severe reduction of maternal feed intake (Dunn et al., 2017), which did not happen with the cows from this study (Fehlberg et al., 2020).

\section{Health}

In the framework of this study, male calves in CON had greater likelihoods to be medicated and treated with antibiotics than males in PRE-L. Nonetheless, females in PRE-L had a tendency for less medications administered than males in PRE-L. The reasons behind

Table 8. Least squares means and associated standard errors for PMN function and phenotyping of lymphocytes of calves throughout the experimental period

\begin{tabular}{|c|c|c|c|c|c|c|c|c|c|c|}
\hline Variable $^{1}$ & $\mathrm{n}$ & \multicolumn{2}{|c|}{ Treatment $^{2}$} & \multicolumn{2}{|c|}{$\operatorname{Sex}^{3}$} & $\mathrm{SE}$ & \multicolumn{4}{|c|}{$P$-value ${ }^{4}$} \\
\hline Phagocytosis & 78 & & & & & & & & & \\
\hline Monocytes & & 23.1 & 25.5 & 24.4 & 24.2 & 1.0 & 0.11 & 0.79 & 0.03 & 0.33 \\
\hline Oxidative burst & 78 & & & & & & & & & \\
\hline Neutrophils & & 86.1 & 87.5 & 87.1 & 86.6 & 1.4 & 0.47 & 0.81 & 0.05 & 0.30 \\
\hline CD4 & & 26.6 & 23.4 & 24.0 & 25.9 & 3.2 & 0.45 & 0.36 & 0.18 & 0.73 \\
\hline CD8 & & 4.0 & 5.6 & 4.4 & 5.2 & 1.0 & 0.67 & 0.74 & 0.10 & 0.84 \\
\hline$\gamma \delta \mathrm{T}$ cells ${ }^{5}$ & 54 & 230 & 232 & 237 & 225 & 24 & 0.05 & 068 & 001 & 073 \\
\hline$\gamma \delta$ & & & 23.2 & 23.7 & 22.5 & 2.4 & 0.95 & 0.68 & 0.01 & 0.73 \\
\hline
\end{tabular}

${ }^{1}$ Data were collected on d 0,7 , and 14 of age (phagocytosis and oxidative burst); data were collected on d 0 and 7 of age (T cells and $\gamma \delta \mathrm{T}$ cells). ${ }^{2}$ Calves were assigned a treatment based on dam's prepartum treatment: Lys (PRE-L) or control (CON).

${ }^{3}$ Calves were divided from males $(\mathrm{M})$ and females $(\mathrm{F})$ in the different treatment groups.

${ }^{4}$ Trt $\times$ sex $\times$ time interaction was not different $(P>0.14)$; trt $\times$ time interaction was not different $(P>0.24)$ except for $\gamma \delta \mathrm{T}$ cells $(P=0.04)$; sex $\times$ time interaction was not different $(P>0.22)$ except for a tendency of oxidative burst neutrophils $(P=0.09)$.

${ }^{5}$ Only 54 out of the 78 calves that finished trial are included within this data; CON-F (n = 12); CON-M (n = 12); PRE-L-F (n = 11); PRE$\mathrm{L}-\mathrm{M}(\mathrm{n}=19)$ 
reduced numbers of medical treatments and sickness during the milk-fed period for calves are not completely understood; however, it is postulated that an improvement in maternal nutritional during late pregnancy could have influenced the intestinal development in the fetus, thus improving future ability of the newborn calf to absorb immunoglobulins from colostrum, as well as to absorb nutrients (Osorio, 2020). The dairy cow diet during gestation can affect fetal and postnatal development and health of the calves (Barua and Junaid, 2015). This was exemplified by Alharthi et al. (2018), who reported enhanced growth of calves in utero and in early-life periods, as well as improved fecal scores upon maternal supplementation with rumen-protected Met (Alharthi et al., 2018). Methionine and Lys comprise the most limiting EAA for milk synthesis. They are often in increased demand before parturition, a period that dairy cows generally experience a negative protein balance, to support both fetal growth in late gestation and milk synthesis postpartum (Drackley, 1999; Larsen et al., 2014). Therefore, the improvement in Lys in the MP had long-term carryover effects on the offspring, probably due to improvements of in utero development of the fetus.

\section{Blood Chemistry Profile, Plasma AA, and Metabolites}

The interaction of treatment and sex indicated the serum total protein was affected by sex for calves in CON but was unaffected by sex for calves in PRE-L. Females in CON had the lesser concentration among all groups. As changes in total protein concentration can happen in response to protein nutrition (Bartlett et al., 2006; Stamey Lanier et al., 2021), it is possible that the lesser concentration of total protein for female calves in $\mathrm{CON}$ reflected the lesser MR CP intake and lesser starter $\mathrm{CP}$ intake of calves in CON. Additionally, research in humans report that males have greater fractional synthesis rate of albumin, independently of protein intake (Thalacker-Mercer et al., 2007). Although serum albumin concentration did not differ between male and female calves in the present study, males tended to have greater total protein concentration than female calves.

In this study, $\mathrm{Cl}$ concentrations tended to be greater for calves in PRE-L-F and PRE-L-M. However, similar to CON-M, sodium concentration was also greater for calves in CON compared with calves in PRE-L. Because all calves were fed the same MR throughout the experiment, the higher $\mathrm{Cl}$ and $\mathrm{Na}$ concentrations could be a result of the administration of electrolytes to the calves due to scours. Indeed, calves in PRE-L-F and in CON-M were more likely to be medicated than calves in PRE-L-M, supporting this hypothesis. Our results indicated that an effect of sex influenced the value of bicarbonate in blood, contrary to what was reported by Dillane et al. (2018), where male calves had greater values than females. Concentrations of bicarbonate in blood can be used as an indicator of health in animals. In the present study, the mean values reported lie within what is considered a normal range of values for calves, which is between 26.3 and $34.1 \mathrm{mmol} / \mathrm{L}$ (Dillane et al., 2018).

The values of anion gap, $\mathrm{P}, \mathrm{Na}, \mathrm{K}$, and $\mathrm{Cl}$ were also between the normal ranges reported by Dillane et al. (2018), but the Ca values were greater. Although serum $\mathrm{Ca}$ is not a reliable direct indicator of $\mathrm{Ca}$ intake, dietary Ca content can influence the amount of serum Ca (Alfaro et al., 1988); therefore, it is possible that differences reported by Dillane et al. (2018) are due to differences in Ca intake, but feed intake was not reported by Dillane et al. (2018). Another possible explanation for differences in serum Ca could be associated with sampling time, which seems to be confirmed by our results and others (Mohri et al., 2007; Dillane et al., 2018). When evaluating serum biochemistry of Holstein dairy calves, Mohri et al. (2007) reported that the sampling time had a significant effect on Ca concentration, with the Ca levels at 24 to $48 \mathrm{~h}$ of age being higher than at d 28, 42, 56, 70, and 84. In the present study, however, Ca concentration on $\mathrm{d} 2$ was the greatest among the sampling dates (d 0, 2, 7, 14, and 28).

Because GGT is recognized as an enzyme throughout the body, with its highest concentration in the liver, we can connect this enzyme to many diseases and health-related issues (Koenig and Seneff, 2015). When GGT levels increase due to damage or dysfunction of the liver, there is also a chain reaction to damage and dysfunction to the red blood cell membranes (Koenig and Seneff, 2015). Serum concentration of GGT are responsive to the amount of colostrum consumed, as reported by Wesselink et al. (1999). In the current study, PRE-L-F had higher concentrations of GGT than CON-F, and CON-M had a higher concentration than PRE-L-M. It is conceivable that differences in efficiency of absorption of colostrum components might be the major factor to influence this difference in circulating GGT, particularly because all calves received the same amount of colostrum replacer at birth instead of colostrum from their dams. These apparent differences in absorption efficiency rates could be a response to treatment as well as to sex. Final maturation of the epithelium for macromolecule absorption needs to occur in the fetal intestine right before birth, as demonstrated by the fact that although intestinal absorption of macromolecules can occur by the fetus, the maximal uptake capacity is much lower than in newborns, and the process takes longer time (Sangild et al., 1999). Thus, we postulated that the maternal supplementa- 
tion with RPL during late gestation might affect the fetus intestinal epithelial maturation in utero. In this study, phagocytosis was elevated for calves in PRE-L compared with calves in CON. The greater concentration of GGT and the greater percentage of phagocytosis agree with the lesser number of days medicated for calves in PRE-L. Alkaline phosphatase is an enzyme used as a marker indicator of liver damage or diseases of skeleton, but not all of its functions are known other than that it might be involved in bone calcification and transport of phosphate into epithelial cells (Sharma, et al., 2014). In cattle, ALP concentration in serum is greater at a young age and decreases as the animals get older (Kaneko, 1997). Additionally, the activity of this enzyme increases after the first intake of colostrum, probably due to the absorption from colostrum and activation in the small intestine (Kurz and Willet, 1991). Additionally, we provide evidence that sex has an effect over the concentration of ALP until at least $28 \mathrm{~d}$ of age, with males having lesser serum concentration of ALP than females. It is possible that this difference according to sex is due to differences in absorption between males and females; however, because there was not an effect of sex on their intakes during this period, additional research is needed to further explain this effect.

Male calves in PRE-L had greater plasma concentrations of total AA. Conventionally, research with dairy calf nutrition evaluates the effects of feeding different compositions of MR or comparing MR with whole milk. In illustration, supplementation of MR with different AA fed to dairy calves from $3 \mathrm{~d}$ to $7 \mathrm{wk}$ increased the blood concentration of AA, such as Met, Lys, Thr and Phe (Yu et al., 2018). Although less research is found regarding the effects of maternal nutrition on postnatal performance of offspring, supplementation of prepartum diets with rumen-protected AA were already shown to affect postnatal calf blood concentration of AA (Alharthi et al., 2018). Alharti et al. (2018) reported that maternal supplementation of rumen-protected Met during late gestation lowered the dairy calf plasma concentration of His, Lys, and Asn. Similarly, our results indicated that the diet fed to dairy cows in the prepartum affected the AA metabolism of the postnatal offspring. Calves in PRE-L had greater Gln compared with calves in CON. Neonatal pig enterocytes decreased glucose oxidation upon addition of glutamine, whereas glutamine oxidation was not affected by addition of glucose (Wu, 1998), demonstrating that glucose oxidation can be spared by glutamine. However, ruminant intestinal tissue may have a different requirement for glutamine oxidation than nonruminant intestinal tissues, as demonstrated by Gate et al. (1999), who reported that glutamine is used for macromolecule synthesis by the portal-drained viscera rather than provision of energy. Thus, it is possible that calves in PRE-L might have macromolecule synthesis due to greater availability of Gln. Ornithine plasma concentration also increased for calves in PREL, which could possibly be due to ornithine and Lys sharing the same transport system, SLC7A1 (solute carrier family 7 member 1; Jungnickel et al., 2018). Thus, an increase in the transport of Lys could also result in an increase in the passage of ornithine. Ornithine is a metabolite of the urea cycle (Rui, 2014) and it is possible that the urea cycle could be stimulated by $\mathrm{C} / \mathrm{EBP} \alpha(\mathrm{CCAAT} /$ enhancer-binding protein $\alpha)$, which also increases the production of aminoacidic substrates for gluconeogenesis (Inoue et al., 2004). In the current study, PRE-L-M concentrations of 3-methylhistidine were greater than that of both female groups as well as the CON-M. Gerrits et al. (1996) reported that differences in 3-methylhistidine are caused by differences in muscle protein mass. It is likely that the lower concentration of 3-methylhistidine concentration in females is due to biological growth differences between males and females in which males have larger muscle mass than females. In the current study, males were larger than females in BW and HG.

\section{Phagocytosis and Oxidative Burst}

Previous research shows that calves are immunologically naïve at birth but can receive passive immunity through colostrum consumption (Chase et al., 2008). Chase et al. (2008) also reported that neonate neutrophils and macrophages have reduced phagocytic ability, but their capacity is increased after colostrum. In our study, all calves received colostrum replacement, and thus both PRE-L and CON gained similar passive immunity from their colostrum consumption. However, our results showed that PRE-L had less days medicated and fewer antibiotics given compared with CON; PRE$\mathrm{L}$ also had higher percentages of phagocytic cells.

The neonate receives a continuous stream of AA and phagocytic cells from the dam through the placenta (Battaglia, 1986). However, phagocytic cells are not developed in the fetus until later in gestation (Barrington and Parish, 2001; Chase et al., 2008), a moment concomitant with the dry period, where we focused the supplementation with RPL. Because all calves received colostrum replacement, the greater percentage of phagocytic neutrophils for calves in PRE-L was likely a result of the maternal diet and in utero effects of it. A higher percentage of phagocytosis could indicate a stronger immune response for calves in the PRE-L group. Indeed, calves in the PRE-L group tended to be healthier, which could be a result of a better develop- 
ment of their immune system from a prenatal period combined with a greater intake of MR during the first 6 wk of life.

\section{CONCLUSIONS}

Nutrition and good health are required for optimal growth and overall well-being. The challenge with dairy calves is through their changeover from a nonruminant animal at birth to a true ruminant once their rumen fully develops. Calves from cows fed RPL during late gestation had greater ADG during the preweaning phase (wk 6-8), which resulted in a greater gain-to-feed ratio in comparison with calves from cows that did not consume RPL. Additionally, calves in PRE-L tended to have a greater intake of $\mathrm{MR}, \mathrm{CP}$, and $\mathrm{ME}$ during the first 6 wk of life than calves in CON. The differences in the concentration of blood metabolites and plasma AA were likely due to the tendency for greater intake of MR for calves in PRE-L. In conclusion, increasing the metabolizable lysine provided to prepartum dairy cows had modest effects on their offspring performance.

\section{ACKNOWLEDGMENTS}

This project was partially supported by Ajinomoto Co. Inc. (Tokyo, Japan) and by the USDA National Institute of Food and Agriculture (Washington, DC; NC-2042). We thank Adisseo (Alpharetta, GA) for the donation of Smartamine M, Dairy Nutrition Plus (Ralston, IA) for the donation of Soyplus, and Phibro Animal Health Corporation (Teaneck, NJ) for the donation of Animate during the course of the experiment. Genuine appreciation is extended to the Dairy Focus Team at the University of Illinois, along with the University of Illinois Dairy Research Unit staff for assisting with data collection and calf health. The authors have not stated any conflicts of interest.

\section{REFERENCES}

Abuelo, A. 2020. Symposium review: Late-gestation maternal factors affecting the health and development of dairy calves. J. Dairy Sci. 103:3882-3893. https://doi.org/10.3168/jds.2019-17278.

Alfaro, E., M. W. Neathery, W. J. Miller, C. T. Crowe, R. P. Gentry, A. S. Fielding, D. G. Pugh, and M. Blackmon. 1988. Influence of a wide range of calcium intakes on tissue distribution of macroelements and microelements in dairy calves. J. Dairy Sci. 71:12951300. https://doi.org/10.3168/jds.S0022-0302(88)79686-1.

Alharthi, A. S., F. Batistel, M. K. Abdelmegeid, G. Lascano, C. Parys, A. Helmbrecht, E. Trevisi, and J. J. Loor. 2018. Maternal supply of methionine during late-pregnancy enhances rate of Holstein calf development in utero and postnatal growth to a greater extent than colostrum source. J. Anim. Sci. Biotechnol. 9:83. https://doi .org/10.1186/s40104-018-0298-1.

Armenta, J. M., D. F. Cortes, J. M. Pisciotta, J. L. Shuman, K. Blakeslee, D. Rosoloson, O. Ogunbiyi, D. J. Sullivan, and V. Shu- laev. 2010. Sensitive and rapid method for amino acid quantitation in malaria biological samples using AccQTag ultra performance liquid chromatography-electrospray ionization-MS/MS with multiple reaction monitoring. Anal. Chem. 82:548-558. https://doi .org/10.1021/ac901790q.

AOAC International. 2002. Official Methods of Analysis. 17th ed. AOAC International.

AOAC International. 2005. Official Methods of Analysis. 18th ed AOAC International.

AOAC International. 2019. Official Methods of Analysis. 21st ed. AOAC International.

Bargo, F., D. H. Rearte, F. J. Santini, and L. D. Muller. 2001. Ruminal digestion by dairy cows grazing winter oats pasture supplemented with different levels and sources of protein. J. Dairy Sci. 84:22602272. https://doi.org/10.3168/jds.S0022-0302(01)74673-5.

Barrington, G. M., and S. M. Parish. 2001. Bovine neonatal immunology. Vet. Clin. North Am. Food Anim. Pract. 17:463-476. https:/ /doi.org/10.1016/S0749-0720(15)30001-3.

Bartlett, K. S., F. K. McKeith, M. J. VandeHaar, G. E. Dahl, and J. K. Drackley. 2006. Growth and body composition of dairy calves fed milk replacers containing different amounts of protein at two feeding rates. J. Anim. Sci. 84:1454-1467. https://doi.org/10 $.2527 / 2006.8461454 x$.

Barua, S., and M. A. Junaid. 2015. Lifestyle, pregnancy and epigenetic effects. Epigenomics 7:85-102. https://doi.org/10.2217/epi.14.71.

Batistel, F., A. S. Alharthi, R. R. C. Yambao, A. A. Elolimy, Y. X. Pan, C. Parys, and J. J. Loor. 2019. Methionine supply during late-gestation triggers offspring sex-specific divergent changes in metabolic and epigenetic signatures in bovine placenta. J. Nutr. 149:6-17. https://doi.org/10.1093/jn/nxy240.

Batistel, F., J. M. Arroyo, A. Bellingeri, L. Wang, B. Saremi, C. Parys, E. Trevisi, F. C. Cardoso, and J. J. Loor. 2017. Ethyl-cellulose rumen-protected methionine enhances performance during the periparturient period and early lactation in Holstein dairy cows. J. Dairy Sci. 100:7455-7467. https://doi.org/10.3168/jds.2017-12689.

Battaglia, F. C. 1986. Placental transport and utilization of amino acids and carbohydrates. Fed. Proc. 45:2508-2512.

Beaty, J. L., R. C. Cochran, B. A. Lintzenich, E. S. Vanzant, J. L. Morrill, R. T. Brandt Jr., and D. E. Johnson. 1994. Effect of frequency of supplementation and protein concentration in supplements on performance and digestion characteristics of beef cattle consuming low-quality forages. J. Anim. Sci. 72:2475-2486. https: //doi.org/10.2527/1994.7292475x.

Bell, A. W., W. S. Burhans, and T. R. Overton. 2000. Protein nutrition in late pregnancy, maternal protein reserves and lactation performance in dairy cows. Proc. Nutr. Soc. 59:119-126. https:// doi.org/10.1017/S0029665100000148.

Carder, E. G., and W. P. Weiss. 2017. Short- and longer-term effects of feeding increased metabolizable protein with or without an altered amino acid profile to dairy cows immediately postpartum. J. Dairy Sci. 100:4528-4538. https://doi.org/10.3168/jds.2016-12362.

Chase, C. C. L., D. J. Hurley, and A. J. Reber. 2008. Neonatal immune development in the calf and its impact on vaccine response. Vet. Clin. North Am. Food Anim. Pract. 24:87-104. https://doi.org/10 .1016/j.cvfa.2007.11.001.

Dairy One. 2009. Forage lab analytical procedures - February 2009. Accessed May 12, 2021. https://dairyone.com/download/forage -forage-lab-analytical-procedures/

Dillane, P., L. Krump, A. Kennedy, R. G. Sayers, and G. P. Sayers. 2018. Establishing blood gas ranges in healthy bovine neonates differentiated by age, sex, and breed type. J. Dairy Sci. 101:32053212. https://doi.org/10.3168/jds.2017-13445.

Donovan, G. A.. I. R. Dohoo, D. M. Montgomery, and F. L. Bennett. 1998. Calf and disease factors affecting growth in female Holstein calves in Florida, USA. Prev. Vet. Med. 33:1-10. https://doi.org/ 10.1016/S0167-5877(97)00059-7.

Drackley, J. K. 1999. ADSA Foundation Scholar Award: Biology of dairy cows during the transition period: The final frontier? J. Dairy Sci. 82:2259-2273. https://doi.org/10.3168/jds.S0022 -0302(99)75474-3. 
Drackley, J. K. 2008. Calf nutrition from birth to breeding. Vet. Clin. North Am. Food Anim. Pract. 24:55-86. https://doi.org/10.1016/ j.cvfa.2008.01.001.

Dunn, A., A. Ashfield, B. Earley, M. Welsh, A. Gordon, M. McGee, and S. J. Morrison. 2017. Effect of concentrate supplementation during the dry period on colostrum quality and effect of colostrum feeding regimen on passive transfer of immunity, calf health, and performance. J. Dairy Sci. 100:357-370. https://doi.org/10.3168/ jds.2016-11334.

Fehlberg, L. K., A. R. Guadagnin, B. L. Thomas, Y. Sugimoto, I. Shinzato, and F. C. Cardoso. 2020. Feeding rumen-protected lysine prepartum increases energy-corrected milk and milk component yields in Holstein cows during early lactation. J. Dairy Sci. 103:11386-11400. https://doi.org/10.3168/jds.2020-18542.

Foster, D. M., and G. W. Smith. 2009. Pathophysiology of diarrhea in calves. Vet. Clin. North Am. Food Anim. Pract. 25:13-36. https:/ /doi.org/10.1016/j.cvfa.2008.10.013.

Gabory, A., T. J. Roseboom, T. Moore, L. G. Moore, and C. Junien. 2013. Placental contribution to the origins of sexual dimorphism in health and diseases: Sex chromosomes and epigenetics. Biol. Sex Differ. 4:5. https://doi.org/10.1186/2042-6410-4-5.

Gao, H., U. Yallampalli, and C. Yallampalli. 2012. Maternal protein restriction reduces expression of angiotensin I-converting enzyme 2 in rat placental labyrinth zone in late pregnancy. Biol. Reprod. 86:31. https://doi.org/10.1095/biolreprod.111.094607.

Gate, J. J., D. S. Parker, and G. E. Lobley. 1999. The metabolic fate of the amino-N group of glutamine in the tissues of the gastrointestinal tract in 24 h-fasted sheep. Br. J. Nutr. 81:297-306. https: //doi.org/10.1017/S0007114599000549.

Gatrell, S. K., L. E. Berg, J. T. Barnard, J. G. Grimmett, K. M. Barnes, and K. P. Blemings. 2013. Tissue distribution of indices of lysine catabolism in growing swine. J. Anim. Sci. 91:238-247. https://doi.org/10.2527/jas.2011-5070.

Gerrits, W. J., G. H. Tolman, J. W. Schrama, S. Tamminga, M. W. Bosch, and M. W. Verstegen. 1996. Effect of protein and proteinfree energy intake on protein and fat deposition rates in preruminant calves of 80 to $240 \mathrm{~kg}$ live weight. J. Anim. Sci. 74:2129. https://doi.org/10.2527/1996.7492129x.

Godfrey, K. M., and D. J. Barker. 2001. Fetal programming and adult health. Public Health Nutr. 4(2b):611-624. https://doi.org/10 .1079/PHN2001145.

Govoni, K. E., T. A. Hoagland, and S. A. Zinn. 2003. The ontogeny of the somatotropic axis in male and female Hereford calves from birth to one year of age. J. Anim. Sci. 81:2811-2817. https://doi .org/10.2527/2003.81112811x.

Haisan, J., Y. Inabu, W. Shi, and M. Oba. 2019. Effects of feeding a high- or moderate-starch prepartum diet to cows on newborn dairy heifer calf responses to intravenous glucose tolerance tests early in life. J. Dairy Sci. 102:8931-8940. https://doi.org/10.3168/ jds.2018-16226.

Heinrichs, A. J. 1993. Raising dairy replacements to meet the needs of the 21st century. J. Dairy Sci. 76:3179-3187. https://doi.org/10 .3168/jds.S0022-0302(93)77656-0.

Holden, L. A., L. D. Muller, G. A. Varga, and P. J. Hillard. 1994. Ruminal digestion and duodenal nutrient flows in dairy cows consuming grass as pasture, hay, or forage. J. Dairy Sci. 77:3034-3042. https://doi.org/10.3168/jds.S0022-0302(94)77245-3.

Inoue, Y., J. Inoue, G. Lambert, S. H. Yim, and F. J. Gonzalez. 2004. Disruption of hepatic C/EBPa results in impaired glucose tolerance and age dependent hepatoesteatosis. J. Biol. Chem. 279:44740-44748. https://doi.org/10.1074/jbc.M405177200.

Jacometo, C. B., A. S. Alharthi, Z. Zhou, D. Luchini, and J. J. Loor. 2018. Maternal supply of methionine during late pregnancy is associated with changes in immune function and abundance of microRNA and mRNA in Holstein calf polymorphonuclear leukocytes. J. Dairy Sci. 101:8146-8158. https://doi.org/10.3168/jds 2018-14428.

Jacometo, C. B., Z. Zhou, D. Luchini, E. Trevisi, M. N. Correa, and J. J. Loor. 2016. Maternal rumen-protected methionine supplementation and its effect on blood and liver biomarkers of energy metabolism, inflammation, and oxidative stress in neonatal Hol- stein calves. J. Dairy Sci. 99:6753-6763. https://doi.org/10.3168/ jds.2016-11018.

Jungnickel, K. E. J., J. L. Parker, and S. Newstead. 2018. Structural basis for amino acid transport by the CAT family of SLC7 transporters. Nat. Commun. 9:550. https://doi.org/10.1038/s41467-018 $-03066-6$.

Kaneko, J. J. 1997. Serum proteins and disproteinemias. Pages 117138 in Clinical Biochemistry of Domestic Animals. J. J. Kaneko, J. W. Harvey, and M. L. Bruss, ed. Academic Press.

Koenig, G., and S. Seneff. 2015. Gamma-glutamyltransferase: A predictive biomarker of cellular antioxidant inadequacy and disease risk. Dis. Markers 2015:818570. https://doi.org/10.1155/2015/ 818570.

Kurz, M. M., and L. B. Willet. 1991. Carbohydrate, enzyme, and hematology dynamics in newborns calves. J. Dairy Sci. 74:21092118. https://doi.org/10.3168/jds.S0022-0302(91)78383-5.

Lapierre, H., L. Doepel, E. Milne, and G. E. Lobley. 2009. Responses in mammary and splanchnic metabolism to altered lysine supply in dairy cows. Animal 3:360-371. https://doi.org/10.1017/ S1751731108003571.

Laporta, J., T. F. Fabris, A. L. Skibiel, J. L. Powell, M. J. Hayen, K. Horvath, E. K. Miller-Cushon, and G. E. Dahl. 2017. In utero exposure to heat stress during late gestation has prolonged effects on the activity patterns and growth of dairy calves. J. Dairy Sci 100:2976-2984. https://doi.org/10.3168/jds.2016-11993.

Larsen, M., H. Lapierre, and N. B. Kristensen. 2014. Abomasal protein infusion in postpartum transition dairy cows: Effect on performance and mammary metabolism. J. Dairy Sci. 97:5608-5622. https://doi.org/10.3168/jds.2013-7247.

Lee, C., N. E. Lobos, and W. P. Weiss. 2019. Effects of supplementing rumen-protected lysine and methionine during prepartum and postpartum periods on performance of dairy cows. J. Dairy Sci. 102:11026-11039. https://doi.org/10.3168/jds.2019-17125.

Licitra, G., T. M. Hernandez, and P. J. Van Soest. 1996. Standardization of procedures for nitrogen fractionation of ruminant feeds. Anim. Feed Sci. Technol. 57:347-358. https://doi.org/10.1016/ 0377-8401(95)00837-3.

Littell, R. C. 2002. Analysis of unbalanced mixed model data: A case study comparison of ANOVA versus REML/GLS. J. Agric. Biol. Environ. Stat. 7:472-490. https://doi.org/10.1198/108571102816.

Lin, X., S. Li, Y. Zou, F. Q. Zhao, J. Liu, and H. Liu. 2018. Lysine stimulates protein synthesis by promoting the expression of ATB $0,+$ and activating the mTOR pathway in bovine mammary epithelial cells. J. Nutr. 148:1426-1433. https://doi.org/10.1093/jn/ nxy140.

Martin, J. L., K. A. Vonnahme, D. C. Adams, G. P. Lardy, and R. N. Funston. 2007. Effects of dam nutrition on growth and reproductive performance of heifer calves. J. Anim. Sci. 85:841-847. https: //doi.org/10.2527/jas.2006-337.

McLean, D. M., and L. F. Bailey. 1972. The effectiveness of three treatments for scouring in calves. Aust. Vet. J. 48:336-338. https: //doi.org/10.1111/j.1751-0813.1972.tb02262.x.

Mertens, D. 2002. Measuring fiber and its effectiveness in ruminants diets. Accessed May 12, 2021. https://cpb-us-e1.wpmucdn.com/ blogs.cornell.edu/dist/6/4340/files/2014/06/MertensPNC2002 -280 goex.pdf

Miura, M., H. Sato, S. Shimizu, M. Nakamura, Y. Miyazawa, T. Fujieda, and I. Shinzato. 2017. Characteristics of a rumen-protected lysine product. 1: Bioavailability of the third generation AjiPro-L. J. Dairy Sci. 100(Suppl. 2):306. (Abstr.)

Mohri, M., K. Sharifi, and S. Eidi. 2007. Hematology and serum biochemistry of Holstein dairy calves: Age related changes and comparison with blood composition in adults. Res. Vet. Sci. 83:30-39. https://doi.org/10.1016/j.rvsc.2006.10.017.

NRC. 2001. Nutrient Requirements of Dairy Cattle. 7th rev. ed. Natl. Acad. Press.

Osorio, J. S. 2020. Gut health, stress, and immunity in neonatal dairy calves: The host side of host-pathogen interactions. J. Anim. Sci. Biotechnol. 11:105. https://doi.org/10.1186/s40104-020-00509-3.

Park, K. T., K. S. Seo, N. A. Godwin, B. J. Van Wie, M. Y. Gulbahar, Y. H. Park, and W. C. Davis. 2015. Characterization and 
expression of monoclonal antibody-defined molecules on resting and activated bovine $\alpha \beta, \gamma \delta \mathrm{T}$ and NK cells. Vet. Immunol. Immunopathol. 168:118-130. https://doi.org/10.1016/j.vetimm.2015 .09.002.

Pink, D. B. S., S. K. Gatrell, R. Elango, J. Turchinsky, A. S. Kiess, K. P. Blemings, W. T. Dixon, and R. O. Ball. 2011. Lysine $\alpha$-ketoglutarate reductase, but not saccharopine dehydrogenase, is subject to substrate inhibition in pig liver. Nutr. Res. 31:544-554. https://doi.org/10.1016/j.nutres.2011.06.001.

Rogers, J. A., U. Krishnamoorthy, and C. J. Sniffen. 1987. Plasma amino acids and milk protein production by cows fed rumen-protected methionine and lysine. J. Dairy Sci. 70:789-798. https://doi .org/10.3168/jds.S0022-0302(87)80075-9.

Rui, L. 2014. Energy metabolism in the liver. Compr. Physiol. 4:177197. https://doi.org/10.1002/cphy.c130024.

Sangild, P. T., J. F. Trahair, M. K. Loftager, and A. L. Fowden. 1999. Intestinal macromolecule absorption in the fetal pig after infusion of colostrum in utero. Pediatr. Res. 45(4, Part 1 of 2):595-602. https://doi.org/10.1203/00006450-199904010-00021.

Sharma, U., D. Pal, and R. Prasad. 2014. Alkaline phosphatase: An overview. Indian J. Clin. Biochem. 29:269-278. https://doi.org/10 $.1007 /$ s12291-013-0408-y.

Stamey Lanier, J. S., F. K. McKeith, N. A. Janovick, R. A. Molano, M. E. Van Amburgh, and J. K. Drackley. 2021. Influence of starter crude protein content on growth and body composition of dairy calves in an enhanced early nutrition program. J. Dairy Sci. 104:3082-3097. https://doi.org/10.3168/jds.2020-19580.

Tarrade, A., P. Panchenko, C. Junien, and A. Gabory. 2015. Placental contribution to nutritional programming of health and diseases: Epigenetics and sexual dimorphism. J. Exp. Biol. 218:50-58. https: //doi.org/10.1242/jeb.110320.

Tautenhahn, A., R. Merle, and K. E. Müller. 2020. Factors associated with calf mortality and poor growth of dairy heifer calves in northeast Germany. Prev. Vet. Med. 184:105154. https://doi.org/ 10.1016/j.prevetmed.2020.105154.

Thalacker-Mercer, A. E., C. A. Johnson, K. E. Yarasheski, N. S. Carnell, and W. W. Campbell. 2007. Nutrient ingestion, protein intake, and sex, but not age, affect albumin synthesis rate in humans. J. Nutr. 137:1734-1740. https://doi.org/10.1093/jn/137.7 .1734 .

USDA. 2010. Heifer calf health and management practices on U.S. Dairy Operations, 2007. USDA-APHIS-VS-CEAH-NAHMS. Fort Collins, CO. Accessed Mar. 16, 2021. https://www.aphis.usda
.gov/animal_health/nahms/dairy/downloads/dairy07/Dairy07_ir CalfHealth.pdf.

van den Borne, J. J., S. J. Alferink, M. J. Heetkamp, A. A. Jacobs, M. W. Verstegen, and W. J. Gerrits. 2012. Asynchronous supply of indispensable amino acids reduces protein deposition in milkfed calves. J. Nutr. 142:2075-2082. https://doi.org/10.3945/jn.112 .165670 .

Waltner-Toews, D., S. W. Martin, and A. H. Meek. 1986. The effect of early calfhood health status on survivorship and age at first calving. Can. J. Vet. Res. 50:314-317.

Warnick, L. D., H. N. Erb, and M. E. White. 1997. The relationship of calfhood morbidity with survival after calving in 25 New York Holstein herds. Prev. Vet. Med. 31:263-273. https://doi.org/10.1016/ S0167-5877(96)01105-1.

Weigler, B. J., D. W. Hird, and W. M. Sischo. 1990. Veterinary and nonveterinary costs of disease in 29 California dairies participating in the National Animal Health Monitoring System from 1988 to1989. J. Am. Vet. Med. Assoc. 196:1945-1949.

Wesselink, R., K. J. Stafford, D. J. Mellor, S. Todd, and N. G. Gregory. 1999. Colostrum intake by dairy calves. N. Z. Vet. J. 47:31-34 https://doi.org/10.1080/00480169.1999.36105.

Wu, G. 1998. Intestinal mucosal amino acid catabolism. J. Nutr. 128:1249-1252. https://doi.org/10.1093/jn/128.8.1249.

Yu, K., M. Matzapetakis, D. Valent, Y. Saco, A. M. De Almeida, M. Terré, and A. Bassols. 2018. Skeletal muscle metabolomics and blood biochemistry analysis reveal metabolic changes associated with dietary amino acid supplementation in dairy calves. Sci. Rep. 8:13850. https://doi.org/10.1038/s41598-018-32241-4.

Zhou, Z., O. Bulgari, M. Vailati-Riboni, E. Trevisi, M. A. Ballou, F. C. Cardoso, D. N. Luchini, and J. J. Loor. 2016. Rumen-protected methionine compared with rumen-protected choline improves immunometabolic status in dairy cows during the peripartal period. J. Dairy Sci. 99:8956-8969. https://doi.org/10.3168/jds.2016 $-10986$.

\section{ORCIDS}

A. R. Guadagnin (ㄴ) https://orcid.org/0000-0002-1446-5082

L. K. Fehlberg (ํ) https://orcid.org/0000-0002-2874-5966

J. K. Drackley @ $\odot$ https://orcid.org/0000-0002-4560-5594

F. C. Cardoso $\odot$ https://orcid.org/0000-0003-1025-3231 